\title{
Imajinasi Kebangsaan di Nusantara: Suatu Kajian Bibliografis
}

\section{KAMARUZZAMAN BUSTAMAM-AHMAD}

UIN Ar-Raniry, Banda Aceh

abah.shatilla@gmail.com

\section{ABSTRACT}

This article aims to examine the social imaginary toward nationalism from theoritical and bibliographical perspectives. Recently, there has been lack of study on imagined nationalism, after Bennedict Anderson had published Imagined Communities. This study by looking at social imagination and cultural memory, will describe the development of imagined nationalism in Nusantara. It will also survey several literatures on concept of nationalism in the region. It is believed that imagined nationalism in Nusantara has been influenced by many concepts from Western scholars. Thus, study on on this issue by emphasing on cultural memory is still needed. It is argued that it is necessary to conduct more research projects on imagined nationalism in Nusantara by focussing on spirit, cosmology, system of knowledge, and values among socities.

Keyword: Nusantara, Imagined Communities, Imagined Nationalism.

\section{ABSTRAK}

Artikel ini membahas tentang imajinasi sosial tentang kebangsaan dari perspektif teoritikal dan bibliografikal. Sejauh ini, kajian imajinasi kebangsaan di Nusantara masih belum begitu mendapatkan perhatian, setelah diterbitkan karya Bennedict Anderson, Imagined Communities. Dalam studi ini, melalui konsep imajinasi sosial dan memori kebudayaan, dicarikan bagaimana perkembangan imajinasi kebangsaan di Nusantara. Selain itu, dilakukan juga penelaahan beberapa literatur tentang konsep nasionalisme di Nusantara. Kajian ini mendapati bahwa imajinasi kebangsaan di Nusantara masih banyak dipengaruhi oleh karya-karya sarjana Barat, sehingga studi imajinasi kebangsaan yang berlandaskan pada memori kebudayaan masih jarang ditemukan. Studi ini pada akhir berargumen bahwa perlu pengkajian secara mendalam tentang imajinasi kebangsaan di Nusantara yang berlandaskan pada spirit, kosmologi, sistem pengetahuan, dan nilai yang berkembang di dalam masyarakat.

Kata Kunci: Nusantara, Imagined Communities,, Imajinasi Kebangsaan. 


\section{PENDAHULUAN}

Studi ini bermaksud untuk mengkaji tentang imajinasi kebangsaan melalui studi bibliografis. Pada prinsipnya, ide awal mengapa kajian ini dilakukan adalah ketika penulis menyelesaikan buku tentang kajian metateori dan metafisika terhadap konsep Islam Nusantara melalui tiga sarjana, yaitu Charles Taylor, Henry Corbin, dan Syed Mohd. Naquib al-Attas. ${ }^{1}$ Dalam penelusuran karya-karya Taylor, ${ }^{2}$ ditemukan buku yang berjudul Modern Social Imaginaries. ${ }^{3}$ Karya tersebut mengupas bagaimana imajinasi sosial dalam masyarakat modern. Lantas, dalam karya Taylor yang lain, Dilemma and Connections: Selected Essays, ${ }^{4}$ terdapat satu bab tentang "Nationalism and Modernity" yang di dalamnya merujuk pada karya Benedict Anderson, Imagined Communities: Reflections on the Origin and Spread of Nationalism. ${ }^{5}$ Taylor menyebutkan bahwa: "Modern nation-states are "imagined communities," in Benedict Anderson celebrated phrase. We might say they have a particular kind of social-imaginary - that is, shared ways in which social spaces are imagined. "6 Konteks imajinasi ini menjadi penting, sebab perlu dipahami konstruksi imajinasi yang dibangun oleh rakyat, kemudian dibingkai dalam satu rajutan nasionalisme.

Kajian mengenai wacana kebangsaan merupakan salah satu dari studi mengenai sistem politik dan pertahanan dan keamanan. ${ }^{7}$ Berbagai negara telah berusaha untuk menyusun arah kebijakan dan strategi yang akan dicapai di masa yang akan datang. ${ }^{8}$ Indonesia sudah mencoba merumuskan bagaimana arah masa depan, sebagaimana terlihat dalam karya Menyongsong 2014-2019: Memperkuat Indonesia dalam Dunia yang Berubah. ${ }^{9}$ Di samping itu, ada juga bagaimana rancang bangun untuk mempersiapkan Indonesia pada tahun 2045. ${ }^{10}$ Namun, upaya yang secara khusus menemukan kembali konsep kebangsaan secara komprehensif memang belum banyak mendapatkan perhatian di kalangan para sarjana. Kendati, para sarjana luar telah melakukan berbagai upaya untuk menemukan bagaimana konsep kebangsaan di tengah-tengah perubahan masyarakat di level internasional. ${ }^{11}$ Bahkan, untuk mempersiapkan suatu masyarakat di masa yang akan datang, telah dikaji melalui konsep planetary civilization, ${ }^{12}$ sebagai upaya apakah suatu negara memilih konsep Conventional Worlds, Barbarization dan Great Transitions. ${ }^{13}$

Melalui konsep-konsep di atas, situasi global akan memainkan pengaruh yang cukup penting di masa yang akan datang. Sebab, perubahan-perubahan di atas akan memasuki setiap negara-negara yang 
memiliki nilai strategis, tidak hanya pada sumber daya alam, tetapi juga bagaimana rekayasa hubungan sosial-budaya, di antara sesama masyarakat. Konsep global citizenship yang mempertemukan berbagai nilai dan moral dari luar suatu negara/blok terhadap negara lain. ${ }^{14}$ Kondisi tersebut mengantarkan pada pengkajian terhadap tata nilai dan tata moral suatu negara oleh negara lain, ${ }^{15}$ yang juga merupakan bagian dari studi metateori. ${ }^{16}$ Indonesia juga telah mulai dikaji aspek masa depan, walaupun hanya sebatas pada perkembangan ekonomi. ${ }^{17}$ Apa yang dipahami untuk melihat keindonesiaan hari ini adalah dikenal dengan istilah Western modernity, dimana dijelaskan oleh Charles Taylor sebagai berikut:

Western modernity is a new conception of the moral order of society. This was at first just an idea in the minds of some influential thinkers, but it later came to shape the social imajinary of large strata, and the eventually whole societies. It has now become to self-evident to us that we have trouble seeing it as one possible conception among others. The mutation of this view of moral order into our social imaginary is the coming to be of certain social forms, which are those essentially characterizing Western modernity: the market economy, the public sphere, and the self-governing people, among others. ${ }^{18}$

\section{NARASI IMAJINASI SOSIAL DI NUSANTARA}

Dalam studi ini, yang hendak dijelaskan adalah tentang konsep imajinasi sosial dalam persoalan kebangsaan. Charles Taylor menjelaskan persoalan ini sebagai berikut:

By social imaginary, I mean something much broader and deeper than the intellectual schemes people may entertain when they think about social reality in a disengaged mode... the ways of people imagine their social existence, how they fit together with others, how things go on between them and their fellows, the expectations that are normally met, and the deeper normative notions and imagine that underlie these expectations.

[T] he term imaginary (i) because... focus is on the way ordinary people "imagine" their social sorroundings, and this is often not expressed in theoretical terms, but it carried in images, stories, and legends. It is also the case that (ii) theory if often the possession of a small minority, whereas what is interesting in the social imaginary is that it is shared by large groups of people, if not the whole society. Which leads to... (iii) the social imaginary is the common understanding that makes possible common practices and a widely share sense of legitimacy. ${ }^{19}$ 
Pemetaan imajinasi kebangsaan merupakan salah satu pra-syarat, supaya suatu bangsa tidak mengalami kegagalan. ${ }^{20}$ Karena itu, pengkajian tentang kosmologi, ideologi, spirit, dan ilmu pengetahuan merupakan alat-alat utama di dalam merekayasa suatu bangsa. Jika keempat hal tersebut tidak diketemukan, maka sistem kebangsaan akan mengalami proses auto pilot. Para pendiri bangsa, selalu mencari akar kosmologi, supaya tatanan kebangsaan akan memberikan impak yang positif, mengenai arah masa depan atau nasib suatu bangsa. Di Nusantara, kajian kosmologi cenderung dipahami sebagai upaya menempatkan manusia dengan alam, manusia dengan pencipta, dan manusia dengan manusia. ${ }^{21}$ Imajinasi yang bersifat abstrak ini yang kemudian digali oleh para pendiri bangsa, supaya fondasi metafisika kebangsaan, akan menjadi akar kebangsaan suatu negara. Dapat dikatakan bahwa kosmologi memberikan dampak pada kekuasaan suatu negara. ${ }^{22}$

Adapun ideologi merupakan salah satu perekat utama di dalam suatu negara. Dalam konteks ini, ideologi merupakan hal yang paling substansi, seperti yang dijelaskan oleh Richard A. Gard berikut:

Ideology may be variously defined as (1) the study of the relation of ideas to language, (2) the manner or content of thinking which is characteristic of an individual or a group, (3) a subjective interpretation of observed social phenomena, (4) a systematic scheme of ideas about life. A survey of ideological issues and problems in Southeast Asia today would disclose at least four important types: philosophical-religious, political, economic, and legal. ${ }^{23}$

Di Indonesia, pengaruh imajinasi sosial juga dilakukan dengan pola di atas, khususnya setelah kemerdekaan, dimana pengaruh Weberian sangat dominan, ${ }^{24}$ terutama pengaruh Clifford Geertz melalui beberapa kajiannya dalam bidang sosial-antropologi pada tahun 1950-an. ${ }^{25}$ Adapun sebelumnya, warna tata nilai yang dibangun merupakan hasil dari pengkajian yang dilakukan oleh C. Snouck Hurgronje. ${ }^{26}$ Kuntowijoyo menuturkan bahwa:

Sebagaimana kita ketahui, selama ini ilmu-ilmu sosial yang diajarkan di perguruan-perguruan tinggi kita adalah ilmu-ilmu sosial Amerika yang sangat dipengaruhi oleh nilai-nilai sosial dan sistem sosial Amerika. Alih-alih dari pada menyembangkan ilmu-ilmu sosial dan humaniora Indonesia yang misalnya diderivasi dari nilai-nilai Pancasila, perguruan-perguruan tinggi kita rupanya malah mengajarkan ilmu-ilmu sosial asing dengan segala biasnya. Oleh karena itu, sebagai organized intelligence di bidang ilmu-ilmu sosial, 
ternyata perguruan-perguruan tinggi kita bukan mengajarkan socialized intelligence, tapi justru Americanised intelligence. Kita menyadari bahwa kesadaran untuk mengembangkan ilmu-ilmu sosial pribumi baru muncul belakangan ini. Upaya untuk melepaskan diri dari kolonisasi ilmu-ilmu sosial masih belum didukung secara institusional oleh perguruan-perguruan tinggi kita. Tentu saja idealnya adalah bahwa ilmu-ilmu sosial yang diajarkan dan dikembangkan harus berakar pada nilai-nilai sosial kita sendiri. ${ }^{27}$

Adapun persoalan lain yang menyangkut tata pikir kebangsaan adalah tentang kosmologi. Di Indonesia sistem kosmologi di setiap daerah jarang diangkat ke permukaan, sebab kosmologi bangsa Indonesia, cenderung hanya dilihat dari aspek Kosmologi Jawa. ${ }^{28}$ Padahal di Indonesia, sistem kosmologi tidak hanya ada di Jawa, tetapi juga ada di daerah-daerah. Demikian pula, dalam hal spirit, dominasi spirit dari Jawa selalu dikedepankan secara simbolik. Namun, ketika diskusi mengenai ideologi, malah ideologi Pancasila yang mengalami proses kontestasi, seiring kemunculan ideologi tandingan di Nusantara saat ini. ${ }^{29}$ Untuk kasus Aceh misalnya, persoalan nasionalisme merupakan persoalan yang begitu krusial, sebab daerah ini sampai sekarang masih merasakan bukan bagian dari bangsa Indonesia. ${ }^{30}$ Sementara Sumatera Barat merupakan daerah yang paling berjasa di dalam menghasilkan gerakan-gerakan sosial keagamaan dan memiliki peran aktif di dalam memberikan fondasi kebangsaan. ${ }^{31}$ Kawasan ini memiliki hubungan yang sangat penting dengan Aceh, namun belakangan dibuat buffer zone oleh Belanda, dengan memisahkan antara Aceh dan Padang, melalui program Kristenisasi di Sumatera Utara. ${ }^{32}$ Konsep buffer zone juga terjadi di Jawa Timur, dimana dipisahkannya antara Bali dan Pulau Jawa melalui keberadaan Islam di wilayah Surabaya. Disadari atau tidak, pola pemisahan ini juga diawali dengan riset oleh Clifford Geertz, dimana dia melakukan penelitian antropologi di Mojokuto dan Bali. Di Mojokuto, ditemukan bagaimana pengaruh Islam terhadap masyarakat, yang oleh Geertz digunakan teori Weberian tentang Calvinisme. Sementara itu, di Bali Geertz menemukan bagaimana pengaruh Hindu terhadap sistem politik. ${ }^{33}$ Dalam salah satu wawancara, Geertz menuturkan bahwa: "I was still quite Weberian at that time." ${ }^{34}$ Kosmologi Bali begitu dominan di dalam melihat cara pandang keindonesiaan, sebagaimana ditemukan dalam beberapa karya para sarjana. ${ }^{35}$ Martin Van Bruinessen mengatakan bahwa: 
Karya-karya Geertz tersebut berdasarkan penelitiannya di kota "Modjokuto" (Pare, Jawa Timur) tahun 1954-1954, tetapi mengandung makna lebih luas: Geertz menawarkan model yang dapat digunakan untuk memahami proses sosial, ekonomi dan politik pada skala nasional: pertikaian politik sebagai konflik antara kelompok-kelompok primodial, proses pemiskinan masyarakat petani sawah, peranan Islam modernis sebagai motor penggerak perkembangan sektor pribumi dan seterusnya. ${ }^{36}$

Selanjutnya, di Sulawesi (Makassar) dan Kalimantan (Dayak) juga masih terkait dengan bagaimana proses imajinasi kebangsaan, terutama dengan persoalan asimilasi kebudayaan, jati diri, dan trans-lokal. Studi tentang hal tersebut dapat dilihat misalnya dalam karya Mikhail Coomans, ${ }^{37}$ Yekti Maunati, ${ }^{38}$ Liana Chua, ${ }^{39}$ William Cummings, ${ }^{40}$ dan Wendy Mee. ${ }^{41}$ Persoalan identitas dan jati diri kedua kawasan tersebut, sering menjadi kajian yang penting, sebelum digali aspek-aspek imajinasi kebangsaan. Namun, aspekaspek kosmologi dan spirit juga menjadi hal yang begitu signifikan, terutama ketika dihubungkan dengan studi perbatasan. Karena dua pulau ini bersentuhan langsung dengan negara luar (Brunei Darussalam, Malaysia, dan Philipina). ${ }^{42}$ Upaya untuk memahami imajinisasi kebangsaan merupakan hal yang sangat urgen untuk diteliti, supaya dapat dipahami bagaimana kontruksi pemahaman kebangsaan, di kalangan masyarakat tersebut.

\section{KONSEP TENTANG IMAJINASI KEBANGSAAN}

Dalam bagian ini disajikan tentang tentang hal ihwal tentang konsep imajinasi kebangsaan. Adapun, istilah kebangsaan dalam bahasa Inggris adalah nationalism. Istilah ini memiliki beberapa penjelasan dalam diskursus nasionalisme. Paling tidak, ada beberapa fase diskursus nasionalisme yang oleh Umut Ozkirimli dibagi ke dalam empat masa. Masa pertama, pada abad ke-18 dan 19 M, ketika gagasan nasionalisme lahir. Di sini muncul para pemikirn seperti Kant, Rousseau, Herder, Fichte, Mill, Lord Acton, Marx, Engels, Lenin, Luxemburg, Bauer, Stalin; sejarawan seperti Michelet, van Treitschke, Renan, dan beberapa teoritikus ilmuwan sosial seperti Durkheim dan Weber. Masa kedua, 1918-1945, ketika kajian nasionalisme menjadi bagian dari studi akademik. Di sini muncul nama-nama seperti Carleton Hayes, Hans Kuhn, dan Louis Snyder. Masa ketiga, 1945-1989, dimana dalam era ini, debat teoritik mengenai nasionalisme menjadi semakin intens dan variatif. Dalam masa ini, muncul nama seperti Daniel 
Lerner, Karl W. Deutsch, dan Elie Kedourie. Masa keempat, dari tahun 1989 sampai sekarang, dimana usaha-usaha untuk memunculkan debat klasik tentang nasionalisme terus bermunculan. ${ }^{43}$

Tampaknya, pengklasifikasian kajian teori nasionalisme dipengaruhi oleh sejarah pemikiran dan perang yang dilakukan oleh Eropa dan Amerika. Perang Dunia pertama tampaknya setelah terjadi era penemuan konsep nasionalisme di Eropa. Adapun fase kedua lebih diwarnai oleh Perang Dunia. Sementara fase ketiga merupakan era Perang Dingin yang diperankan oleh Amerika Serikat. Sementara yang terakhir, persis setelah keruntuhan Uni Sovyet pada tahun 1989. Setelah itu, perang lebih banyak diwarnai seperti yang terjadi paska-1989 di Timur Tengah. Dalam ruang sejarah tersebut, nasionalisme ditampilkan di dunia ini. Akibatnya, pola dan wajah nasionalisme pun sangat beragam, yang muncul di Eropa dan Amerika Serikat. Akibatnya, proses penyusunan sejarah nasionalisme di dunia ini baru berusia kurang lebih 4 abad. Walaupun, dalam sejarah pemikiran Islam di Timur Tengah, konsep nasionalisme juga dapat ditemukan secara konseptual, namun tentu saja agak berbeda dengan apa yang dipraktikkan di Eropa. Jika Ozkirimli mendasarkan pada para pemikiran sarjana, maka Hollbrad mendasarkan pada tipologi nasionalisme yang berkembang di Eropa.

Dalam hal ini, Carsten Holbraad membagi beberapa tipe nasionalisme yang muncul di Eropa: nasionalisme konservatif, nasionalisme liberal, dan nasionalisme sosialis. ${ }^{44}$ Adapun nasionalisme konservatif berawal dari sistem negara-negara Eropa pada abad ke-16, 17, 18 M., Revolusi Perancis dan peperangan oleh Napoleon, aliran politik yang bersifat realisme, dan kemunculan konsep nasionalitas. Nasionalisme konservatis memiliki dua tipe: defensif dan agresif. Tipe defensif (bertahan) memiliki karakter melawan solidarisme konservatif dan bentuk-bentuk progresifitas internasionalisme. Adapun tujuannya adalah untuk kedaulatan nasional dan kewujudan tatanan international. Dalam hal ini, tipe pertama ini lebih berpusatkan pada konsep negara-bangsa. Adapun titik fokus dari aliran ini adalah kepentingan nasional, hak-hak, nilai-nilai dan keamanan. Pengaruh tipe ini pada akhir abad ke-19 dan pertengahan abad ke-20 M. Adapun tokoh-tokohnya adalah Canning, Disraeli, De Daulle, dan Thatcher. Sementara tipe yang kedua yakni nasionalisme konservatif agresif, memiliki karakter adanya upaya pembebasan dari pengaruh luar, mengeksklusikan kelompok-kelompok minoritas, kaji ulang terhadap perbatasan, adanya 
keinginan untuk melakukan imperialisme, adanya elemenn fasisme, dan tertarik dengan kekerasan.

Dalam menyusun nasionalisme sebagai sesuatu yang dibayangkan oleh masyarakat, Taylor memberikan dua hal penting tentang imajinasi modern, yaitu: ada perubahan dalam masyarakat dari yang bersifat hirarkhi "mediated-acces societies" ke kondisi yang bersifat horizontal "direct-access societies." 45 Kondisi masyarakat yang dimediasi di dalam mendapatkan akses kerap terjadi di dalam masyarakat tradisional. Mereka masih memiliki hirarkhi yang amat kuat, untuk mendapatkan "keistimewaan" dalam status sosial, pengaruh, dan dominasi yang terkadang didasarkan pada latar belakang seorang individu. ${ }^{46}$ Namun, dalam masyarakat modern, masyarakat sudah mendapatkan akses secara langsung, tidak lagi melihat latarbelakang atau status sosial yang mereka emban. Dalam proses perpindahan masyarakat tersebut, konsep nasionalisme terbangun di dalam suatu imajinasi bersama di antara sesama rakyat. Taylor menyebutkan bahwa ada wilayah publik, dimana masyarakat mendapatkan akses yang tidak perlu lagi dimediasi. ${ }^{47}$ Wilayah ini kemudian melahirkan pasar sebagai bagian dari aktifitas ekonomi. Keadaan ini, menurut Taylor sebagai "the rise of the modern citizenship state." ${ }^{48}$

Adapun yang kedua menurut Taylor, bayangan sosial modern tidak dilihat lagi dari "translocal entities" sebagai dasar bagai sesuatu yang lain, yang tinggi, daripada aksi di dalam era sekular. ${ }^{49}$ Pernyataan ini memang agak susah dipahami, mengingat konsep nation lahir di dalam era modern, dimana hal-hal yang bersifat multi-lokal tidak lagi begitu signifikan. Namun, dalam studi tentang negara bangsa, paling tidak ada beberapa komponen yang mendasar yang mengikat suatu bangsa, yaitu: etnik, religi, teritorial, ras, kelompok campuran..$^{50}$ Beberapa komunitas tersebut kemudian melebur dalam suatu bingkai negara-bangsa. Di situ ada ideologi yang dipandang sebagai nasionalisme dan ideologi juga yang dianggap sebagai sistem ide. ${ }^{51}$ Dengan begitu, mengkaji tentang nasionalisme, pada prinsipnya adalah mengkaji tentang bagaimana imajinasi bangsa yang dimiliki oleh kelompok etnik, religi, ras, dan kelompok masyarakat campuran. Hampir semua kelompok tersebut merupakan entitas dari translokal, dimana menurut Taylor tidak menjadi begitu penting di era modern.

Lebih lanjut, Anthony $\mathrm{H}$, Birch memberikan satu gambaran konsep mengenai kajian kebangsaan, yang dipilah menjadi tiga, yaitu sosiologi, kebudayaan, dan institusional. Dari sosiologi, memunculkan konsep 
kelompok persaudaraan, suku, etnik, komunitas, dan masyarakat. Sedangkan dari kebudayaan, muncul konsep bahasa, sastra, religi, budaya, dan peradaban. Adapun dari institusional, muncul kotamadya, kabupaten, provinsi, negara, dan kerajaan. ${ }^{52}$ Menurut Jacobsohn, dalam proses institusionalisasi, dimaksudkan bahwa fungsi negara itu terletak pada lembaga, bukan pada individu. ${ }^{53}$ Ketiga kelompok konsep tersebut kemudian memunculkan identitas, ideologi, dan wilayah, untuk mewujudkan suatu bangsa. Tampaknya, imajinasi kebangsaan itu muncul dari konsep-konsep sosiologi dan kebudayaan, jika bukan antropologi. Adapun dalam dataran institusi, disitu dipahami bahwa sistem ide yang terjabarkan secara sistematik dan mengikat, diimplementasikan oleh lembaga-lembaga pemerintahan tertentu. Karena itu, ada pendapat yang mengatakan bahwa negara yang gagal dikarenakan institusi kenegaraan tidak berfungsi sebagaimana mestinya. Hal ini terlihat misalnya dalam pernyataan berikut:

Nations fail today because their extractive economic institutions do not create the incentives needed for people to save, invest, and innovative. Extractive political institutions support these economic institutions by cementing the power of those who benefit from extraction. Extractive economic and political institutions, though their detail vary under different circumstances, are always at the root of the failure. ${ }^{54}$

Penjabaran di atas menunjukkan bahwa kajian bangsa pada awalnya, bukanlah pada dataran kekuasaan, tetapi pada memori dan warisan dalam dalam aspek sosial-kebudayaan, yang pada gilirannya wujud imajinasi kebangsaan. Berikut ada beberapa definisi tentang bangsa yang dirangkum oleh Muthiah Alagappa:

According to Ernest Renan (1970), two things help constitute a nation: One is the common possession of a rich heritage of memories; the other is the desire to live together and preserve the inheritance that has been handed down. The nation is an outcome of a long-past of efforts and belief in a shared or common destiny. In a similar but distinct vein Benedict Anderson (1991) asserts that a nation is an imagined community that is limited and sovereign. The nation is imagined because even the members of the smallest community may not know each other. Yet the image of such a community lives in the minds of its members. A nation is limited in that it cannot comprise all of humanity or even broad segments of it. It refers to a specific group. A nation is sovereign as it is the ultimate source of authority for all those who belong to it. Finally the nation is a community "because regardless of the actual inequality and exploi- 
tation that may prevail, the nation is always conceived as a deep, horizontal comradeship." It is that fraternity that makes it possible for members to die willingly for the nation.

In my view, common history, shared destiny, and a set of beliefs are crucial in the making of a nation. I subscribe to the idea that nations are imagined and constructed, and that nationalism precedes and constructs nations. However, nations cannot be imagined at will.Cultural and political history and circumstances are crucial. Often, nationalism selectively deploys mytho-history and culture in the construction of persuasive narratives for a nation. ${ }^{55}$

Beberapa penjelasan di atas memperlihatkan bahwa bangsa adalah berkenaan dengan "berbagai memori," "keyakinan," "kesamaan tujuan," "imajinasi masyarakat," "kedaulatan," "otoritas puncak." Bahkan, Muthiah meringkaskan cara membuat suatu bangsa yakni dengan memiliki kesamaan sejarah, berbagi identitas, dan ada satu keyakinan. Hampir semua ungkapan di atas terkait dengan apa yang bisa dikumpulkan sebagai suatu kekuatan di dalam membangun suatu bangsa: sejarah, keyakinan, dan tujuan yang hendak dicapai.

Di dalam sejarah suatu bangsa sudah tentu memiliki memori kolektif yang menyebabkan rakyatnya bersatu di dalam bingkai suatu kesatuan. Pengelolaan memori kolektif inilah yang memberikan dasar yang kuat, bagaimana bentukan imajinasi masa lalu, untuk menuju masa yang akan datang. Jan Assmann membagi ada empat memori yang terdapat di dalam suatu masyarakat. Pertama, memori meniru. Memori ini berkenaan dengan aksi. Masyarakat belajar berbagai bentuk tindakan melalui imitasi atau meniru. ${ }^{56}$ Tampaknya, budaya meniru memang kerap terjadi di dalam masyarakat, dari masa lalu hingga sekarang. Memori ini kemudian membentuk suatu aksi yang menjadi ingatan bagi semua instrumen masyarakat. Kedua, memori tentang sesuatu. Kajian tentang memori ini berkenaan dengan bagaimana masyarakat mendefinisikan sesuatu di dalam kehidupan mereka, yang pada gilirannya menunjukkan siapa masyarakat tersebut. Memori ini juga akan membawa masyarakat tersebut tidak hanya pada masa kini, tetapi juga dalam fase dan tahapan masa lalu. ${ }^{57}$ Ketiga, memori komunikatif. Adapun memori di sini adalah bahasa dan kemampuan berkomunikasi di dalam interaksi masyarakat. ${ }^{58}$ Terakhir, memori kultural. Ini adalah penyatuan dari ketiga aspek memori sebelumnya, dimana meniru, sesuatu, bahasa, dan komunikasi memberikan makna bagi 
masyarakat tersebut. ${ }^{59}$ Memori kebudayaan, karena dia merupakan penyatuan dari tiga memori sebelumnya, pada gilirannya membentuk identitas di dalam masyarakat tersebut. Karena semua memori ini dimaknai oleh masyarakat. Dalam konteks bangsa yang bersifat multi-kultur, tampaknya tidak akan ada semua memori kebudayaan yang ditampilkan di dalam pentas sejarah bangsa. Muthiah Alagappa mengatakan bahwa etnisitas telah mendominasi pembentukan bangsa di Asia. ${ }^{60}$

Konsep kajian etnik di dalam nasionalisme ini juga dapat dilihat dalam karya Anthony Reid. ${ }^{61}$ Dalam hal ini, Reid menyebutkan ada enam faktor penting tentang ethnie nationalism di Asia, yaitu: nama kolektif, mitos yang sama tentang asal usul, kesamaan sejarah atau tradisi, keunikan kebudayaan biasanya dalam bidang bahasa dan religi, asosiasi dalam suatu wilayah, dan ada rasa persatuan. ${ }^{62}$ Dalam karya ini, Reid menyoroti beberapa suku bangsa yang ada di Asia Tenggara yang memiliki unsur nasionalisme etnik, yakni: Melayu, Aceh, Batak, dan Kadazan di Malaysia. Dengan kata lain, jika keenam unsur tersebut disatukan pada masingmasing etnik tersebut, maka konsep nasionalisme etnik akan melekat secara kuat, seperti Nasionalime Melayu, Bahasa Melayu, Budaya Melayu, Persatuan Melayu, Tanah Melayu, dan seterusnya. Karena itu, di dalam nasionalisme etnik, masing kuat rasa persatuan untuk identitas dalam hal budaya, religi, dan bahasa. Di samping itu, kesamaan lintasan sejarah juga menjadi hal yang cukup signifikan di dalam membangun rasa nasionalisme. Namun, setelah kemunculan konsep nation-state, nasionalisme etnik memudar, secara persalah berubah menjadi bagian penyemaian rasa nasionalisme dalam kontek tidak lagi mengedepankan keenam tersebut.

Lebih lanjut, Francis Fukuyama membedakan proses bangunan negara (state building) dan bangunan nasional, sebagai berikut:

State building refers to the creation of tangible institutions - armies, police, bureaucracies, ministries, and the like. It is accomplished by hiring staf, training officials, giving them offices, providing them with budgets, and passing laws and directives. Nation building, by contrast, is the creation of a sense national identity to which individuals will be loyal, and identity that will supersede they loyalty to tribes, villages, regions, or ethnic groups. Nation building in contrast to state building requires the creation of intangible things like national traditions, symbols, shared historical memories, and common cultural points of reference. National identities can created by state through their policies on language, religion, and education. But they are just as often estab- 
lished from the bottom up by poets, philosophers, religious leaders, novelists, musicians, and other individuals with no direct access to political leaders. ${ }^{63}$

Jika merujuk pada pendapat Fukuyama di atas, maka imajinasi kebangsaan dimulai dari bawah sampai kemudian menjadi suatu negara. Uniknya, mereka yang menghasilkan pemikiran, malah sama sekali tidak terlibat di dalam pelaksanaan tata kenegaraan. Di sini, terlihat bahwa sesuatu yang tidak dapat diraba malah menjadi faktor pendukung di dalam kajian kebangsaan. Dengan kata lain, kekuatan pemikiran atau ide-ide yang abstrak mampu mengisi kekuatan kebangsaan, pada saat pendirian negara. Tidak sedikit filosof yang menghasilkan pemikiran malah tidak terlibat di dalam mengurusi lembaga-lembaga kenegaraan. Mereka bahkan terkadang berada dibalik layar. Kehadiran mereka kemudian digiring pada pemenuhan konseptualisasi tradisi, simbol, memori sejarah, dan kesamaan dasar kebudayaan. Karena itu, dapat dikatakan bahwa imajinasi kebangsaan harus digali dari pemikir-pemikir besar yang menghasilkan ide-ide untuk kewujudan kebangsaan bagi suatu negara. Tidak mengherankan mana kala dibalik pendirian suatu negara, terdapat nama-nama pemikir dengan gagasan-gagasan yang mempersatukan rakyat di dalam bingkai satu konsep kebangsaan.

Satu lagi hal yang menarik yaitu ketika kebangsaan hendak diwujudkan, ada upaya keras untuk memidahkan kepatuhan seseorang dari wilayahnya yang bersifat etnisitas ke teritori yang dikenal sebagai sebuah negara. Upaya ini tentu saja sangat berkaitan dengan imajinasi politik. Jan Assmann di dalam menjelaskan imajinasi politik melewati melalui tiga hal yakni: identitas, kesadaran, dan refleksitas. ${ }^{64}$ Terkait dengan identitas, Assmann membagi ke dalam jenis yaitu: identitas personal dan identitas kolektif. Di sini, Assmann melihat bagaimana "Saya" versus "kita" di dalam membangun identitas. ${ }^{65}$ "Saya" memiliki dua identitas yaitu identitas individual dan identitas personal. ${ }^{66}$ Adapun penjelasan kedua identitas tersebut adalah sebagai berikut: "Individual identity is the coherent self-image that builds itself up in the consciousness of the individual through features that (a) distinguish them significantly from everyone else and (b) remain constant across the various phases of their development." ${ }^{67}$ Adapun identitas personal adalah "...the embodiment of all of the roles, qualities, and talents that give the individual hiw own special place in the social network." 68 Kedua penjelasan ini memperlihatkan bahwa identitas 
seseorang tersebut sangat terkait dengan sosio-genik dan kebudayaan yang sudah terkonstruk di sekitarnya. Di sini kesadaran seseorang sangat dipengaruhi oleh bahasa, gagasan-gagasan, norma-norma, dan nilai yang ada di dalam waktu dan budaya tertentu. ${ }^{69}$ Setelah identitas "Saya" dapat diketahui, maka identitas personal dan individual berubah menjadi identitas kolektif. Assmann menegaskan bahwa identitas kolektif sangat ditentukan secara simbolik dan adanya konstruksi imajiner. ${ }^{70}$

Jika seperti di atas bentuk indentitas individu dan kolektif, maka yang perlu digali adalah bagaimana sisi-sisi kebudayaan mempengaruhi seseorang di dalam merefleksikan kedua identitas yang melekat pada dirinya (individu dan personal). Kontruksi sosial lantas membentuk pemahaman bagaimana "Saya" mengaktualisasikan diri dan pikiran bersamaan dengan identitas individu lainnya, baik personal maupun individual. Di dalam hubungan sosial dan kebudayaan tersebutlah, kemudian simbol-simbol yang memiliki makna menjadi suatu kesepakatan antara masing-masing individu tersebut, dimana kemudian dijadikan sebagai identitas bersama. Hal-hal seperti bahasa, norma, gagasan, dan nilai merupakan juga produk budaya di dalam satu lorong waktu sejarah. Masyarakat memerlukan masa lalu sebagai bentuk dari self-definition. ${ }^{71}$ Di sini, Assmann menyimpulkan bahwa: "The imagined national community is based on an imagined continuity that reaches back in the depths of time." 72 Tampaknya, imajinasi kebangsaan itu diasaskan pada konteks masa lalu yang memberikan dasar-dasar imajinasi untuk menuju pada identitas kolektif. Di sinilah muncul istilah yang kemudian banyak mendapat perhatian di dalam kajian kebangsaan yaitu social and political imaginaire. ${ }^{73}$

Sebagai contoh, dalam sejarah imajinasi politik di Indonesia, dominasi Nasionalisme Jawa begitu kuat sebagai kekuatan mayoritas. Etnik lainnya diletakkan pada sub-ordinasi, sehingga hampir semua elemen nasionalisme etnik melekat secara kuat di negara ini. Dengan kata lain, konsep kekuasaan Jawa begitu mendominasi kajian nasionalisme di Indonesia. ${ }^{74}$ Karena itu, imajinasi kebangsaan di Indonesia tidak akan lepas dari imajinasi Jawa di dalam sejarah bangsa ini. Karena itu, membuka wacana tentang kajian kebangsaan di dalam konteks keindonesiaan masa kini memiliki beberapa persoalan penting, terkait dengan sistem kosmologi, spirit, ideologi, dan ilmu pengetahuan. Dari aspek sistem kosmologi, Indonesia dikuasai oleh sistem kosmologi Jawa. ${ }^{75}$ Dari aspek spirit, Indonesia dikuasai oleh spirit Hindu dan Buddha. Dari aspek ideologi, masih terjadi proses kontestasi, 
baik terbuka maupun tertutup, di dalam memahami hakikat ideologi bangsa. ${ }^{76}$ Dari aspek ilmu pengetahuan, rekayasanya masih berkiblat pada ilmu-ilmu dari Barat. ${ }^{77}$ Kondisi ini memperlihatkan imajinasi kebangsaan di Indonesia belum mengindonesia, dimana sistem kosmologi, ideologi, spirit, dan ilmu pengetahuan dari luar orbit Pulau Jawa tidak mendapatkan tempat di dalam peneguhan nasionalisme di Indonesia.

Gema negara-bangsa atau dikenal dengan istilah nation-states memang bukan muncul di negara tanpa suatu proses sejarah. Kekuasaan suatu bangsa tentu saja menyisir aspek daratan, air, dan udara ke seluruh penjuru dunia. Ketiga aspek tersebut kemudian diberikan wilayah perbatasan atau teritori. Kekuasaan yang berbasiskan religi, pada hakikatnya, tidak mengenal wilayah perbatasan, sebagaimana kekuasaan suatu negara. Kekuasaan berbasiskan pada etnik juga mengalami batas, dimana tersebut terlihat saat ada perbedaan identitas anatara masing-masing etnik. Pertanyaannya adalah apakah konsep nasionalisme yang sekarang berubahan menjadi internasionalisme atau kosmopolitanisme memakai kerangka penyebaran sebagaimana pengalaman diaspora religi di beberapa benua? Bennedict Anderson menyebutkan bahwa terdapat tiga hal penting yang hilang di dalam pikiran manusia yang diistilahkan oleh Anderson sebagai persepsi kebudayaan:

The first... was the idea that a particular script-language offered privileged ontological truth, precisely because it was an inseparable part of that truth. It was this idea that called into being the great transcontinental sodalities of Christendom, the Islamic Ummah, and the rest. Second was the belief that society was naturally organized around and under high centre - monarchs who were persons apart from other human beings and who ruled by some form of cosmological (divine) dispensation. Human loyalties were necessarily hierarchical and centripetal because the ruler, like the sacred script, was a node of access to being and inherent in it. Third was a conception of temporality in which cosmology and history were inditinguishable, the origins of the world and of men essentially identical. ${ }^{78}$

Dari kutipan di atas memperlihatkan bahwa nasionalisme telah menghilangkan apa yang menjadi dasar imajinasi masyarakat secara substantif. Imajinasi kebangsaan menghilangkan kekuatan makna ontologi dari teks-teks suci dari pikiran manusia. maksudnya, sebagai bagian dari pengaruh agama melalui kitab suci terhadap pikiran manusia telah disirnakan oleh imajinasi kebangsaan. Dengan kata lain, imajinasi 
kebangsaan memotong pengaruh teks keagamaan di dalam pikiran manusia untuk mencari makna kebenaran ontologis. Harus diakui bahwa kebenaran ontologi merupakan bagian terpenting di dalam pikiran masyarakat. Di situ mereka menemukan hakikat suatu kebenaran yang diyakini oleh akal pikiran manusia. Oleh Bennedict hakikat kebenaran ontologi merupakan persepsi kebudayaan yang paling utama.

Selanjutnya, imajinasi kebangsaan juga menghilangkan kekuatan ilahiyah yang melekat pada sosok individu yang menjadi pemimpin di dunia. Pemimpin yang memiliki garis tangan secara ilahi tidak lagi menjadi begitu penting. Karena di era modern, dimana imajinasi kebangsaan muncul, persoalan keilahian menjadi tidak begitu penting. Adapun bagi masyarakat yang berada dibawah sistem monarkhi sosok pemimpin dipandang sebagai "bayangan" Tuhan di muka bumi. Jika tesis Anderson di atas benar adanya, maka sangat wajar jika kemudian segala sesuatu sistem pemerintahan yang diusung melalui nasionalisme sehakikatnya adalah buah dari proses sekularisasi yang menjadi bayi dari pemikiran Barat.

Sehingga sejak awal kelahiran modernisme dan nasionalisme, nasib pemikiran divinitas menjadi begitu pahit adanya. Yahudi menderita sampai kemudian ditemukan konsep Zionisme. Islam mendapatkan dampak yang luar biasa saat keruntuhan Khilafat di Turki saat Perang Dunia I. Adapun lorong waktu yang disediakan untuk perjalanan imajinasi kebangsaan adalah via modernisme dan sekularisme. Ada yang mendefinisikan sekularisme sebagai "a political mode of governance based on two principles - equality of respect and freedom conscience - and two operative modes - separation of church and state and the neutrality of the state toward religions and toward secular philosophy movement."79 Melalui konsep sekularisme seperti itulah, imajinasi kebangsaan dimunculkan. Dua aspek utama dalam sekularisme yaitu persamaan di dalam kehormatan dan kebebasan hati nurani menjadi hal penting. Sebab, semua orang berusaha ditempatkan di dalam posisi yang sederajat. Sementara itu, sistem kebenaran ontologi yang muncul dari lembaga keagamaan mis. gereja, tidak lagi muncul di dalam sistem kenegaraan. Konsep pemisahan lembaga keagamaan dengan negara memang sudah sering didengunkan dalam kajian sekularisme..$^{80}$ Charles Taylor menyebutkan bahwa "...when people argue that since the "secular" is an old category of Christian culture, and since Islam doesn't seem to have a corresponding category, therefore Is- 
lamic societies cannot adopt secular regimes." ${ }^{81}$

Namun, negara harus tidak ikut campur di dalam gerakan filsafat sekular, sangat jarang dimunculkan di dalam perdebatan secara terbuka. Sebagai contoh, dampak sekular terhadap religi adalah ketika pada abad ke-19 didirikan Masyarakat Sekular (Secular Society) oleh G.J. Holyoake di Inggris, yang bertujuan untuk "... a just world order and moral program of individual action that would address human problems without the use of supernatural explanation."82 Inilah konsekuensi logis penggunaan istilah sekular yang kemudian digiring di dalam kajian ilmu sosial. Mengapa hal ini menjadi penting? Hal ini disebabkan imajinasi kebangsaan yang berbarengan dengan penyebaran sekularisme terjadi setelah era Reformasi. Taylor menyebutkan setelah era tersebut, "... certain functions, properties, and institutions were transferred from church control to that laymen." 83 "Orang Biasa" inilah yang menggerakkan pemikiran demi pemikiran yang kemudian menjadi geraka filsafat modern. "Orang Gereja" tidak mampu lagi mengontrol manusia diluar gereja untuk berekspresi, sebagaimana sebelum Era Reformasi.

Keadaan di atas merupakan konsekuensi logis dari aspek kedua dan ketiga yang ditegaskan oleh Bennedict Anderson di atas, yaitu imajinasi kebangsaan menghilangkan sistem kosmologi dan sejarah. Tentu sistem kosmologi dan sejarah yang digunakan sebagai basis imajinasi kebangsaan secara resmi adalah mereka yang mendominasi sejarah suatu bangsa. Kehilangan kosmologi dalam pikiran manusia pada gilirannya merupakan bentuk keterputusan manusia itu sendiri dengan asal usul mereka. Sehingga imajinasi kebangsaan memberikan mudarat kebudayaan secara kosmik. Alhasil, tiga hal yang hilang di atas merupakan basis utama di dalam persepsi kultural yang dibangun oleh setiap etnik bangsa di dunia ini. Oleh karena kehilangan seluruh pusat kendali persepsi kebudayaan, maka pengaruh gerakan filsafat modern menyisir hampir seluruh dunia.

Keterputusan agama, divinitas, kosmologi, dan sejarah, diganti oleh tata pikir dari Barat. Inilah puncak imajinasi kebangsaan di era modern. Benedict menulis bagaimana kemunculan imajinasi kebangsaan sebagai berikut: "... the convergence of capitalism and print technology on the fatal diversity of human language created the possibility of a new form of imagined community." 84 Keterhubungan antara kapitalisme dan teknologi cetak yang membuat adanya kemunculan imajinasi kebangsaan. Tentu saja kapitalisme merupakan bagian dari imperialisme dan kolonialisme 
yang dilakukan oleh pihak negara-negara di Eropa. Sementara dunia percetakan merupakan salah satu cara distribusi ide-ide yang diistilah di atas sebagai "secular philosophy movement." Gagasan dari pemikiran Barat telah mengubah citra dan hala tuju sejarah dunia. Di sebutkan bahwa "Comte (1998), Marx (1978), Weber ([1904] 1930), and Durkheim ([1912] 1995) each forecast that in modern society, positivism, rationality, and science would displace the theological, enchanted, religiously oriented perspective held by earlier civilizations." ${ }^{185}$

Demikianlah beberapa uraian mengenai imajinasi kebangsaan yang berangkat dari imajinasi sosial. Studi di atas memperlihatkan bahwa imajinasi kebangsaan semestinya dilihat dari akar rumput, bukan dari menara gading. Narasi bagian ini memperlihatkan bahwa secara teoritik, imajinasi kebangsaan di Indonesia tampaknya belum mampu mengikat suasana kebatinan seluruh rakyat Indonesia. Hal ini disebabkan, sistem kosmologi, spirit, ideologi, dan ilmu pengetahuan masih belum begitu mengkristalkan di dalam perjalanan sejarah negara-bangsa di Indonesia. Sehingga, imajinasi kebangsaan lebih banyak diproduksi oleh negara yang memang sudah mendapatkan pengaruh dominan konstruksi teoritiknya dari pemikiran-pemikiran yang tidak senafas dengan kenusantaraan. Akhirnya, Indonesia masih perlu tersebut menggali aspek kosmologi lokal yang ada di seluruh Nusantara yang selama ini telah ditenggelamkan melalui proses pembumian nasionalisme melalui model di atas.

\section{KARYA-KARYA TENTANG IMAJINASI KEBANGASAAN}

Lebih lanjut, studi tentang imajinasi kebangsaan merupakan kajian yang muncul setelah Perang Dunia ke-2. Dalam konteks Asia Tenggara, kemunculan negara-negara baru merupakan gejala kebangkitan nation state yang setelah kemerdekaan yang diperoleh, setelah selesai Perang Dunia ke-2. Hal ini terlihat dalam karya-karya berikut: Justus M. Van Der Kroef yang berjudul "Society and Culture in Indonesian Nationalism, "86 Karya Der Kroef lebih melihat aspek masyarakat dan kebudayaan di dalam mengkaji tentang nasionalisme di Indonesia. selanjutnya, Howard M. Federspiel juga mengkaji tentang kebangsaan dengan judul "Islam and Nationalism." ${ }^{87}$ Studi Howard ini merupakan telaah terhadap wujud kebangsaan dalam publikasi Al-Lisaan yang terbit pada tahun 1944. Karya Howard kemudian dilanjutkan dengan judul Sultans, Shamans, and Saints: Islam and Muslims in Southeast Asia. ${ }^{88}$ Studi ini menjelaskan konsep buffer zone diterapkan 
untuk memetakan kekuatan Islam dan nasionalisme di Asia Tenggara, dari era sebelum penjajahan, hingga era kemerdekaan. Karya yang mengupas hal yang agak mirip, namun melihat koneksinya dengan keadaan di Timur Tengah, dapat dibaca di dalam studi Michael Franciss Laffan, Islamic Nationhood and Colonial Indonesia: The Umma Below the Winds. ${ }^{89}$ Studi Laffan kemudian dilanjutkan dengan karya mengenai proses pembentukan Indonesia dengan judul The Makings of Indonesian Islam. ${ }^{90}$ Karya-karya Laffan lebih mengedepankan pendekatan sejarah, di dalam melihat aspek kebangsaan di Indonesia, dengan menukilkan peran jaringan intelektual dan kesadaran Islamisme di dalam pembangunan imajinasi kebangsaan di Nusantara.

Adapun studi yang sangat mempengaruhi tentang imajinasi kebangsaan di Indonesia adalah karya Benedict Anderson yaitu Imagined Communities: Reflections on the Origin and Spread of Nationalism. ${ }^{91}$ Karya yang telah diterjemahkan ke dalam lebih 20 bahasa ini, sangat mempengaruhi tentang bagaimana konstruksi imajinasi kebangsaan, tidak terkecuali untuk kasus Indonesia. Karya lanjutan tentang nasionalisme oleh Ben Anderson dilanjutkan dengan judul Spectre of Comparisons: Nationalism, Southeast Asia, and the World. ${ }^{92}$ Kendati Ben Anderson melihat secara regional, namun perhatiannya terhadap Indonesia sangat besar sekali, sebagaimana dijumpai dalam dua karya tersebut. Hanya saja, pendekatan Ben Anderson lebih banyak bertumpu pada sejarah dan politik, yang terjadi di Indonesia, ketimbang dari aspek budaya dan nilai-nilai yang wujud di provinsi-provinsi di Nusantara ini. Harus diakui bahwa konsep Imagined Communities telah mempengaruhi cara pandang studi kebangsaan di Indonesia. Selanjutnya, studi yang melihat aspek agama dan nasionalisme di Indonesia juga dilakukan oleh beberapa sarjana. Misalnya, studi Charles E. Farhadian, Christianity, Islam, and Nationalism in Indonesia. ${ }^{93}$ Studi Fahardian melihat pengaruh agama di dalam Orde Baru dan juga bagaimana perkembangan agama Kristen di Papua.

Adapun studi imajinasi kebangsaan dapat ditemukan dalam dua karya yaitu: Heirs to world culture Being Indonesian 1950-1965 yang diedit oleh Jennifer Lindsay dan Maya H.T. Liem. ${ }^{94}$ Buku kumpulan tulisan ini merupakan hasil potret bagaimana menjadi Indonesia pada kurun waktu 19501965. Selanjutnya karya menjadi Indonesia juga dihasilkan oleh para penulis Muslim Indonesia dengan judul Menjadi Indonesia: 13 Abad Eksistensi Islam di Bumi Nusantara diedit oleh Komaruddin Hidayat dan A. Gaus. ${ }^{95}$ 
Di sini, para penulis menyajikan bagaimana inter play antara Islam, nasionalisme dan keindonesiaan, terjadi dalam kurun waktu 13 abad lebih. Kedua karya tersebut mampu memberikan narasi dari berbagai dimensi mengenai bagaimana menjadi Indonesia di dalam berbagai tantangan zaman. Hanya saja, karya-karya seperti ini lebih banyak bertumpu pada perspektif historis ditambah dengan kekuatan reflektif para penulis, khususnya mereka yang menjadi pelaku dan saksi sejarah. Sementara itu, kajian mengenai kontruksi kebangsaan juga dilakukan oleh beberapa penulis. Dalam hal ini, studi Muthiah Alagappa yang berjudul Nation Making In Asia: From Ethnic to Civic Nations? dapat dijadikan contoh bagaimana proses konseptualisasi kebangsaan, yang terjadi Asia, tidak terkecuali di Indonesia. ${ }^{96}$ Konstruksi kebangsaan yang diketengahkan oleh Alagappa sangat menarik dapat dapat dijadikan sebagai salah satu pijakan dalam studi ini, dimana dia menyebutkan 5 argumen, yaitu:

First, in multi-ethnic countries, constructing nations on the basis of majority communities implicitly or explicitly led to the formation of minority communities and their destruction or marginalization. Disadvantaged or marginalized groups became apprehensive about their futures, stimulating alternative conceptions of nation as well as imagination of new states in which minority communities would become the staatsvolk or state-bearing nations. That in turn created apprehensions among new minority communities setting a vicious cycle in motion. The demand for new nations and states frequently led to violence and war. In a few cases, such domestic conflicts invited international military intervention.

Second, ethno-national imaginations in homogenous populations were nonaccepting of divided nations and of the idea that one nation may support more than one state. The quest for unification of divided nations and the effort to achieve congruence between nation and state were primary causes of several inter-state wars including irredentism in Asia since 1945.

Third, ethnic-nation making challenged, modified, and in some cases undermined civic nation-making, fostering internal conflict in those states.

Fourth, ethnic-nation making polarised populations making them intolerant and unaccepting of plurality and diversity. The forging of a cohesive national community became much more difficult if not impossible.

Finally, it made societies intolerant of migration (international flow of labour in a globalized world) and exacerbated racially-based animosities between certain exclusive ethnic nation-states. ${ }^{97}$

Selanjutnya, studi mengenai kontruksi kebangsaan juga dapat dibaca 
dalam karya yang diedit oleh Wang Gungwu dengan judul Nation-Building: Five Southeast Asian Histories. ${ }^{98}$ Di dalam karya ini, disorot bagaimana konstruksi kebangsaan di lima negara (Malaysia, Indonesia, Singapura, Philipina, dan Thailand). Adapun yang mengajikan tentang bangunan kebangsaan di Indonesia adalah Anthony Reid. Melalui narasi sejarah, Reid menjabarkan perjalanan kebangsaan ketika kemerdekaan terjadi di negara ini. Selain itu, studi Reid tentang kebangsaan juga dapat dilihat dalam karyanya, Imperial Alchemy: Nationalism and Political Identity in Southeast Asia. ${ }^{99}$ Studi ini mengulas bagaimana perjalanan kebangsaan di Asia Tenggara. Setelah itu, Reid juga mengupas tentang beberapa perhadapan etnik dengan kebangsaan, ${ }^{100}$ yaitu Cina, Melayu, Aceh, dan Batak. Hanya saja, pendekatan Reid lebih banyak mengacu pada aspek sejarah, ketimbang aspek kosmologi dan nilai-nilai yang terkandung di dalam etniketnik tersebut dalam melakukan kontribusi terhadap kebangsaan. Selanjutnya, kajian yang bersifat teoritik mengenai kebangsaan di Asia Tenggara, juga dapat dibaca dalam karya Nicholas Tarling yang berjudul Nationalism in Southeast Asia. ${ }^{101}$ Karya Tarling dapat dianggap sebagai salah satu karya yang membedah berbagai dimensi mengenai kebangsaan di Asia Tenggara. Dalam karya tersebut, Tarling mengupas tentang kontruksi kebangsaan dari negara-negara yang sudah dijajah menjadi negara yang merdeka.

Adapun karya lain yaitu studi Joel S. Kahn, Other Malays: Nationalism and Cosmopolitanism in the Modern Malay World. ${ }^{102}$ Melalui pendekatan sejarah dan antropologi, Joel mengulas bagaimana perjalanan nasionalisme dan kosmopolitanisme di Dunia Melayu. ${ }^{103}$ Karya ini melihat bagaimana perjalanan orang Melayu di Malaysia, Singapura, dan Sumatera Barat. Dapat dikatakan bahwa studi ini telah memberikan suatu kontruksi kebangsaan melalui konsep kosmopolitanisme di Asia Tenggara. Hanya saja, Joel tidak menyentuh aspek etnik Jawa, Dayak, dan Makassar, sebagaimana yang akan dilakukan dalam penelitian ini. Adapun Joel sendiri merupakan antropolog yang menekuni tentang budaya dan nilai-nilai orang Minangkabau. ${ }^{104}$ Hanya saja, kajian Joel lebih banyak diarahkan pada Dunia Melayu di Malaysia dan Singapura, ketimbang konteks keindonesiaan.

Karya-karya di atas merupakan studi awal mengenai kontruksi kebangsaan yang ditulis oleh para sarjana luar negeri. Tampak bahwa, kajian imajinasi kebangsaan yang ditelaah oleh para sarjana di atas, lebih 
banyak dilihat dari aspek regionalitas melalui pendekatan sejarah, politik, dan sosial-humaniora. Dalam beberapa tahun terakhir, penulis dari Indonesia pun tidak lepas dari studi mereka tentang kebangsaan. Salah satu karya yang mendalam (reflektif) adalah karya Djoko Santoso dan Ahmad Syafii Maarif. Adapun Djoko Santoso menulis buku Menggagas Indonesia Masa Depan yang berisi tentang rasa kebangsaan dan mencari sosok kepimpinan bagi Indonesia. ${ }^{105}$ Djoko menjabarkan imajinasi kebangsaan dalam pilar kebangsaan, ideologi bangsa, dan nasionalisme sebagai identitas bangsa. Karya ini lebih merupakan renungan seorang mantan perwira terhadap nasib bangsa Indonesia dan menawarkan jalar keluar dari kemelut yang dialami oleh bangsa ini. Adapun karya Ahmad Syafii Maarif berjudul Islam dalam Bingkai Keindonesiaan dan Kemanusiaan: Sebuah Refleksi Sejarah. ${ }^{106}$ Karya Ahmad ini merupakan upaya penempatan Islam di dalam konstelasi kebangsaan Indonesia. Karena bersifat kumpulan tulisan dan reflektif, buku ini dapat dijadikan sebagai salah satu sumber bagaimana memahami imajinasi kebangsaan dalam perspektif religisiusitas.

Adapun karya lain yang berusaha untuk melakukan re-imajinasi kebangsaan dapat dilihat dalam karya As'ad Said Ali dan Yudi Latif. Kedua penulis ini mengupas bagaimana imajinasi kebangsaan dari ideologi Pancasila. Karya As'ad berjudul Negara Pancasila: Jalan Kemaslahatan Berbangsa merupakan buku yang secara komprehensif menerangkan bagaimana bentuk kenegaraan Indonesia dalam berbagai konteks permasalahan pencarian jatidiri bangsa (politik, demokrasi, agama dan negara, kebijakan, dan ideologi bangsa). ${ }^{107}$ Sementara karya Yudi Latif adalah Negara Paripurna: Historisitas, Rasionalitas, dan Aktualitas Pancasila. ${ }^{108}$ Karya Yudi ini menyajikan tafsiran setiap inti-inti yang terdapat di dalam setiap pasal dalam Pancasila. Tafsiran Pancasila ini merupakan upaya serius bagaimana mewujudkan imajinasi kebangsaan di dalam konteks kekinian. Hanya saja, kedua karya di atas, belum mengupas pada aspek-aspek nilai-nilai yang mesti di gali dari setiap sistem kosmologi suku bangsa yang ada di Indonesia, sehingga dapat ditarik pada ranah kajian ke-Pancasila-an.

Selanjutnya, karya Daoed Joesoef yang berjudul Studi Strategi: Logika Ketahanan dan Pembangunan Nasional juga berusaha mengupas tentang perjalanan bangsa dalam perspektif kajian strategis. Buku ini berusaha menempatkan Indonesia dalam kajian yang lebih luas, dimana di dalamnya juga ditelaah tentang kontruksi kebangsaan. Sepintas, karya Daoed Joesoef 
hampir mirip dengan karya Ali Murtopo yaitu: Strategi Politik Nasional. ${ }^{109}$ Karya-karya seperti ini merupakan karya yang berusaha menggiring imajinasi kebangsaan di dalam perspektif ilmu pertahanan, sebagaimana juga terlihat dalam karya Makmur Supriyatno, Tentang IImu Pertahanan. ${ }^{110}$ Karena itu, studi ini juga berkaitanan erat dengan persoalanan imajinasi kebangsaan dalam perspektif ilmu strategi atau ilmu pertahanan negara. Kendati karya-karya mereka tidak didasarkan pada apa yang dipikirkan oleh rakyat Indonesia, tetapi apa yang dipikirkan oleh para aparatur negara. Dalam konteks ini, perlu berusaha untuk menjelajahi apa yang dibayangkan oleh rakyat Indonesia, lalu dikonseptualisasikan dalam kajian pertahanan dan keamanan negara. Hal ini paling tidak dapat dilihat dalam karya Lawrence Freedman yang berjudul Strategy: A History. ${ }^{111}$

\section{KESIMPULAN}

Studi ini masih dapat dikatakan sebagai studi pendahuluan di dalam proyek pengkajian penulis mengenai imajinasi sosial di dalam imajinasi kebangsaan. Namun begitu, di dalam paparan di atas dapat digarisbawahi beberapa hal. Pertama, di dalam menyongsong 100 tahun kemerdekaan Indonesia pada tahun 2045, persoalan imajinasi kebangsaan perlu dilihat kembali. Sebab jika tidak diperhatikan secara seksama, maka sangat boleh jadi imajinasi kebangsaan yang muncul pada generasi ini akan memberikan masalah di dalam merekatkan semangat persatuan dan kesatuan bangsa Indonesia. Studi ini, paling tidak telah memberikan penjelasan bagaimana konsep imajinasi kebangsaan yang ternyata lebih banyak dipengaruhi dari luar Indonesia, ketimbang dari dalam negara ini. Hal tersebut terbukti bahwa rekayasa kebangsaan di Indonesia merupakan rekayasa paskaperang dunia kedua, dimana sebagian modelnya adalah menjauhkan kosmologi, spirit, dan ilmu pengetahuan dari negara yang baru dimerdekakan pada tahun 1940-an. Kedua, konsep nasionalisme sesungguhnya belum final, terutama di kalangan para sarjana dan juga praktik kenegaraan, paling tidak di Asia Tenggara. Model-model nasionalisme di Asia Tenggara menunjukkan bagaimana kekuatan etnik di dalam peneguhan jati diri kebangsaan. Karena itu, di rangkaian imajinasi kebangsaan sejatinya tidak mengabaikan etnik-etnik yang ada di Nusantara, jika ingin melihat kembali imajinasi sosial di dalam imajinasi kebangsaan. Secara teoritik, artikel ini telah memberikan langkah-langkah untuk melihat memori kebudayaan yang dapat merekat suatu imajinasi 
kebangsaan. Melalui memori kebudayaan maka imajinasi kebangsaan tidak lagi dilihat melalui pandangan Anderson di atas, dimana dilihat produksi intelektual. Ketiga, melalui studi terhadap beberapa karya tentang nasionalisme di Nusantara terlihat bahwa kontruksi meta-teori yang dibangun masih bersifat melihat aspek masa lalu melalui berbagai perspektif. Pola ini pada dasarnya perlu lebih dipetakan bentuk kekinian wajah penduduk Indonesia, sebab studi-studi yang telah ada hanya merespon rekayasa sosial yang berbasiskan pada teori-teori modern semata.

\section{CATATAN AKHIR}

1 Kamaruzzaman Bustamam-Ahmad, Kontribusi Charles Taylor, Syed Muhammad Naquib Al-Attas, and Henry Corbin dalam Studi Metafisika $\mathbb{E}$ Meta Teori terhadap Islam Nusantara di Indonesia (Banda Aceh: Bandar Publishing, 2017).

2 Untuk lanskap karya Taylor, baca juga Kamaruzzaman Bustamam-Ahmad, "Mempertimbangkan Kontribusi Charles Taylor terhadap Studi Agama di Indonesia," Episteme 11, no. 2 (2016): 225-59.

3 Charles Taylor, Modern Social Imaginaries (London: Duke University Press, 2004).

4 Charles Taylor, Dilemmas and Connections: Selected Essays (Cambridge: The Belknap Press of Harvard University Press, 2011).

5 Benedict Anderson, Imagined Communities: Reflections on the Origin and Spread Nationalism (New York: Verso, 2006).

6 Taylor, Dilemmas and Connections: Selected Essays, 86.

7 Studi mutakhir mengenai hal ini, dapat dibaca dalam Henry Kissinger, World Order (New York: Penguin Press, 2014). Francis Fukuyama, Political Order and Political Decay: From the Industrial Revolution to the Globalization of Democracy (New York: Farrar, Straus and Giroux, 2014). Francis Fukuyama, The Origins of Political Order: From Prehuman Times to French Revolution (New York: Farrar, Straus and Giroux, 2012). Francis Fukuyama, The Great Disruption: Human Nature and the Reconstruction of Social Order (New York: The Free Press, 1999). Francis Fukuyama, "Reconceptualizing Democracies and Empowering Them to Deliver," in Democracy in U.S. Security Strategy: From Promotion to Support, ed. oleh Alexander T.J. Lennon (Washington DC.: Center for Strategic and International Studies, 2009), 55-74.

8 Untuk konteks Amerika Serikat, baca National Intelligence Council, "Global Trends 2015: A Dialoque About the Future With Nongovernement Experts" (National Intelligence Council, 2000). National Intelligence Council, "Global Trends 2025: A Transformed World" (National Intelligence Council, 2008). National Intelligence Council, "Global Trends 2030: Alternative Worlds" (Director of National Inteligence, 2012). National Intelligence Council, "Mapping the Global Future: Report of the National Intelligence Council's 
2020 Project" (National Intelligence Council, 2004). Untuk konteks Uni Eropa, lihat Institute for Security Studies, "Global Governance 2025: At a Critical Juncture" (Paris: The European Union Institute for Security Studies, 2010).

9 Muhammad AS Hikam, Menyongsong 2014-2019: Memperkuat Indonesia dalam Dunia yang Berubah (Jakarta: Badan Intelijen Negara (BIN) dan Rumah Buku, 2014).

10 Kuntjoro-Jakti Dorojatun, Menerawang Indonesia Pada Dasawarsa Ketiga Abad Ke-21 (Jakarta: Alvabet, 2012).

11 Lihat bagaimana skenario masa depan yang dipaparkan oleh Al Gore dalam Al Gore, The Future (New York: WA Allen, 2013). Demikian pula, konsep masyarakat di era digital society dalam Eric Schmidt dan Jared Cohen, The New Digital Age: Reshaping the Future of People, Nation and Business (London: John Murray, 2014). European Internet Foundation, "The Digital World" (European Internet Foundation, 2009).

12 Mengenai bagaimana arah Planetary Civilization, baca Michio Kaku, Physics of the Future: How Science Will Shape Human Destiny and Our Daily Lives by the Year 2100 (New York: Anchor Books, 2012). Sam Mickey, On The Verge of a Planetary Civilization: A Philosophy of Integral Ecology (London: Rowman \& Littlefield International, Ltd, 2014).

13 Paul Raskin et al., "Bending the Curve: Toward Global Sustainability" (Sweden: Stockholm Environment Institute, 1998). Paul Raskin et al., "Branch Points: Global Scenarios and Human Choice” (Sweden: Stockholm Environment Institute, 1997). Paul Raskin et al., "Great Transition: The Promise and Lure of the Times Ahead" (Boston: Tellus Institute, 2002). Paul Raskin, "The Great Transition Today" (Boston: Tellus Institute, 2006). Paul Raskin, Orion Kriegman, dan Josep Xercavins, "We the People of Earth: Toward Global Democracy" (Boston: Tellus Institute, 2010).

14 Mengenai konsep ini, lihat April Carter, The Political Theory of Global Citizenship (New York: Routledge, 2001). Baca juga Bryan S. Turner, Religion and the Modern Society: Citizenship, Secularization and the State (New York: Cambridge University Press, 2011).

15 Lihat beberapa hasil riset berikut: Pew Research Center, "The Future of the Global Muslim Population: Projections for 2010-2030” (Washington, D.C.: Pew Research Center's Forum on Religion \& Public Life, 2011). Pew Research Center, "A Portrait of Jewish Americans" (Washington, D.C.: Pew Research Center's Forum on Religion \& Public Life, 2013). Pew Research Center, "Faith on the Move: The Religious Affiliation of International Migrants” (Washington, D.C.: Pew Research Center's Forum on Religion \& Public Life, 2012). Pew Research Center, "Global Christianity: A Report on the Size and Distribution of the World's Christian Population" (Washington, D.C.: Pew Research Center's Forum on Religion \& Public Life, 2011). Pew Research Center, "The Global Religious Landscape: A Report on the Size and Distribution of the World's Major Religious Groups as of 2010" (Wash- 
ington, D.C.: Pew Research Center's Forum on Religion \& Public Life, 2012). Pew Research Center, "U.S.Religious Landscape Survey Religious Beliefs and Practices: Diverse and Politically Relevant" (Washington, D.C.: Pew Research Center's Forum on Religion \& Public Life, 2008).

16 Di Indonesia, studi ini telah dimulai seperti terlihat di dalam T.M. Soerjanto Poespowardojo dan Alexander Seran, Filsafat Ilmu Pengetahuan: Hakikat Ilmu Pengetahuan Kritik terhadap Visi Positivisme Logis, serta Implikasinya (Jakarta: Kompas, 2015). Adapun mengenai kajian meta-teori, lihat Roger Sibeon, Rethinking Social Theory (London: Sage Publications, 2004).

17 Raoul Oberman et al., "The Archipelaco Economy: Unleashing Indonesia's Potential” (McKinsey Global Institute, 2012).

18 Charles Taylor, Modern Social Imaginaries (London: Duke University Press, 2004), 2. Mengenai moral order di era modern, lihat Charles Taylor, Sources of The Self: The Making of The Modern Identity (Cambridge: Harvard University Press, 1989).

19 Taylor, Modern Social Imaginaries, 23.

20 Mengenai teori negara gagal, baca Daron Acemoglu dan James A. Robinson, Why Nations Fail: The Origins of Power, Prosperity, and Poverty (London: Profile Books, 2012).

21 Loius Leahy, Kosmos, Manusia dan Allah (Yogyakarta: Kanisius, 1986). Hairudin Harun, Kosmologi Melayu dalam Era Teknologi Maklumat (Kuala Lumpur: Dewan Bahasa dan Pustaka, 2001). Undang A. Darsa dan Edi S. Ekadjati, Gambaran Kosmologi Sunda (Bandung: Kiblat, 2004).

22 Tony Day dan Craig J. Reynolds, "Cosmologies, Truth Regimes, and the State in Southeast Asia," Modern Asian Studies 34, no. 1 (2000): 1-55.

23 Richard A. Gard, "Ideological Problems in Southeast Asia," Philosophy East and West 2, no. 4 (1953): 293.

24 Lihat Hanneman Samuel, Genealogi Kekuasaan Ilmu Sosial Indonesia: Dari Kolonialisme Belanda Hingga Modernisme Amerika (Jakarta: Kepik Ungu, 2010).

25 Lihat Clifford Geertz, The Religion of Java (Chicago: The University of Chicago Press, 1960). Clifford Geertz, Local Knowledge: Further Essays in Interpretitve Anthropology (New York: Basic Books, 1983). Clifford Geertz, Negara:The Theatre State in Nineteenth-Century Bali (New Jersey: Princeton University Press, 1980). Clifford Geertz, The Interpretation of Cultures: Selected Essays (New York: Basic Books, 1973). Fred Inglis, Clifford Geertz: Culture, Customs and Ethics (Cambridge: Polity Press, 2000).

26 Harry J Benda, "Christian Snouck Hurgronje and the Foundations of Dutch Islamic Policy in Indonesia," The Journal of Modern History 30, no. 4 (1958): 338-47. Mengenai Snouck Hurgronje lihat Jan Just Witkam, "Christiaan Snouck Hurgronje A Tour d'horizon of his Life and Work," in Christiaan Snouck Hurgronje (1897-1936) (Leiden: Leiden University Library, 2007), 1131. Jan Just Witkam, "Introduction: Christiaan Snouck Hurgronje's Description of Mecca," in Mekka in the Latter Part of the 19th Century, oleh C. Snouck Hurgronje (Leiden: Brill, 2007), xiii-xxi. 
27 Kuntowijoyo, Paradigma Islam: Interpretasi untuk Aksi (Bandung: Mizan, 2008), 588-89.

28 Lihat misalnya Franz Magnis-Suseno, Etika Jawa: Sebuah Analisa Falsafi tentang Kebijaksaan Hidup Jawa (Jakarta: Gramedia, 2003). (Suyono, 2007) P.J. Zoetmulder, Manunggaling Kawula Gusti: Pantheisme dan Monisme dalam Sastra Suluk Jawa (Jakarta: Gramedia, 1995).

29 Diskursus ini dapat dibaca dalam As'ad Said Ali, Negara Pancasila: Jalan Kemaslahatan Berbangsa (Jakarta: LP3ES, 2010). Faisal Ismail, Ideologi Hegemoni Dan Otoritas Agama: Wacana Ketegangan Kreatif Islam Dan Pancasila (Yogyakarta: Tiara Wacana ', 1999). Kuntowijoyo, "Radikalisasi Pancasila," Kompas, 21 2001. Oka Puniatmaja, "Dharma, Pancasila dan Pembangunan Manusia Seutuhnya," in Agama dan Tantangan Zaman: Pilihan Artikel Prisma 1975-1984 (Jakarta: LP3ES, 1985). M. Sastrapratedja, "Ideologi Pancasila Dalam Pembangunan Karakter Bangsa,” in Budaya Bagi Bangsa, ed. oleh Toety Heraty Noerhadi (Jakarta: AIPI, 2012), 142-60. Abdurrahman Wahid, "Pancasila Sebagai Ideologi Dalam Kaitannya dengan Kehidupan Beragama dan Berkepercayaan Terhadap Tuhan Yang Maha Esa," in Pancasila Sebagai Ideologi dalam Berbagai Bidang Kehidupan Bermasyarakat, Berbangsa, dan Bernegara (Jakarta: BP-7 Pusat, 1992), 163-68.

30 Kamaruzzaman Bustamam-Ahmad dan M. Hasbi Amiruddin, Ulama, Separatisme, dan Radikalisme di Aceh (Yogyakarta: Kaukaba and LSAMA, 2013). Mengenai studi tentang kontestasi keindonesiaan, keacehan, dan keislaman, lihat Ishak Otto Syamsuddin, Aceh Pasca Konflik: Kontestasi 3 Varian Nasionalisme (Banda Aceh: Bandar Publishing, 2013). Mengenai kisah perlawanan orang Aceh terhadap Indonesia, lihat Hasan Tiro, "Konsep-Konsep Kunci Ideologi Acheh Merdeka," Suara Acheh Merdeka, no. VII (1996): 2937. Husaini M. Hasan, Dari Rimba Aceh ke Stockholm (Jakarta: Batavia Publishing, 2015). Murizal Hamzah, Hasan Tiro: Jalan Panjang Menuju Damai Aceh (Banda Aceh: Bandar Publishing, 2014). Mengenai kajian nasionalisme dan Aceh, lihat Edward Aspinnall, Islam and Nation: Separatist in Aceh, Indonesia (California: Stanford University Press, 2009). Edward Aspinnall, "Sovereignty, the Successor State, Universal Human Rights: History and International Structuring of Acehnese Nationalism," Indonesia, no. 73 (2002): 1-24. Edward Aspinnall, "From Islamism to Nationalism in Aceh, Indonesia," Nations and Nationalism 13, no. 2 (2007): 245-63.

31 Kajian tentang nasionalisme dan Padang, lihat misalnya Christine Dobbin, Gejola Ekonomi Kebangkitan Islam, dan Gerakan Padri: Minangkabau 1784-1847, trans. oleh Tedjasudhana Lilian D. (Depok: Komunitas Bambu, 2008). Azyumardi Azra, Surau Pendidikan Islam Tradisional Dalam Transisi Dan Modernisasi (Jakarta: Logos, 2003). Michael Franciss Laffan, Islamic Nationhood and Colonial Indonesia: The Umma Below the Winds (New York: Routledge, 2003). Mengenai konteks historisitas, lihat Anthony Reid, Imperial Alchemy: Nationalism and Political Identity in Southeast Asia (Cambridge: Cambridge University Press, 2010). Anthony Reid, An Indonesian Frontier: Acehnese $\mathbb{E}$ Other 
Histories of Sumatra (Singapore: Singapore University Press, 2005).

32 Baca Bungaran Antonius Simanjuntak, ed., Pemikiran tentang Batak Setelah 150 Tahun Agama Kristen di Sumatera Utara (Jakarta: Yayasan Obor Indonesia, 2011).

33 Clifford Geertz, "Form and Variation in Balinese Structure," American Ethnologist 61 (1959): 991-1012.

34 Richard Handler, "An Interview with Clifford Geertz," Current Anthropology 32, no. 5 (1991): 605.

35 Lihat misalnya Fred B. Eiseman, Bali: Sekala and Niskala (Singapore: Periplus, 1990). Miguel Covarrubias, Island of Bali (Singapore: Periplus, 1973).

36 Martin Van Bruinessen, "Kata Pengantar," in Geger Tengger: Perubahan Sosial dan Perkelahian Politik, oleh Robert W. Hefner (Yogyakarta: LKiS, 1999), xxxiii. Lihat misalnya beberapa studi yang menggunakan model Geertz, (Beatty, 2001) (Lukens-Bull, 2005)

37 Mikhail Coomans, Manusia Daya: Dahulu, Sekarang, Masa Depan (Jakarta: Gramedia, 1987).

38 Yekti Maunati, Identitas Dayak: Komodifikasi dan Politik Kebudayaan (Yogyakarta: LKiS, 2004).

39 Liana Chua, The Christianity of Culture: Conversion, Ethnic Citizenship, and the Matter of Religion in Malaysian Borneo (New York: Palgrave, 2012).

40 William Cummings, "Islam, Empire, and Makasarese Historiography in the reign of Sultan Alauddin (1593-1639)," Journal of Southeast Asian Studies 38, no. 2 (2007): 197-214.

41 Wendy Mee, "A Traffic in Songket: Translocal Malay Identity in Sambas," Journal of Southeast Asian Studies 41, no. 2 (2010): 331-329.

42 Lihat misalnya studi Bruno Bottignolo, Celebrations with the Sun: An Overview of Religious Phenomena among the Badjaos (Manila: Ateneo de Manila University Press, 1995). H. Arlo Nimmo, Magosaha: An Ethnography of the Tawi-Tawi Sama Dilaut (Manila: Ateneo de Manila University Press, 2001).

43 Umut Ozkirimli, Theories of Nationalism: A Critical Introduction (London: Palgrave Macmillan, 2010), 10.

44 Carsten Holbraad, Internationalism and Nationalism in European Political Thought (New York: Palgrave Macmillan, 2003).

45 Charles Taylor, Dilemmas and Connections: Selected Essays (Cambridge: The Belknap Press of Harvard University Press, 2011), 86.

46 John A Jacobson, An Introduction to Political Science (London: Wadsworth Publishing Company, 1998), 17.

47 Taylor, Dilemmas and Connections: Selected Essays, 87.

48 Ibid.

49 Ibid.

50 Martha L. Cottam dan Richard W. Cottam, Nationalism E्E Politics: The Political Behaviour of Nation States (Colorado: Lynne Rienner, 2001), 28.

51 Ibid., 7.

52 Anthony H. Birch, The Concepts and Theories of Modern Democracy (New York: 
Routledge, 2001), 17.

53 Jacobson, An Introduction to Political Science, 18.

54 Acemoglu dan Robinson, Why Nations Fail: The Origins of Power, Prosperity, and Poverty, 372.

55 Muthiah Alagappa, Nation Making in Asia: From Ethnic to Civic Nations? (Kuala Lumpur: Institute of Strategic and International Studies (ISIS) Malaysia, 2012), 8. Cetak miring dari penulis.

56 Jan Assmann, Cultural Memory and Early Civilization: Writing, Remembrance, and Political Imagination (New York: Cambridge University Press, 2011), 5.

57 Ibid., 6.

58 Ibid.

59 Ibid., 6-7.

60 Alagappa, Nation Making in Asia: From Ethnic to Civic Nations?, 6.

61 Reid, Imperial Alchemy: Nationalism and Political Identity in Southeast Asia.

62 Ibid., 7.

63 Francis Fukuyama, Political Order and Political Decay: From the Industrial Revolution to the Globalization of Democracy (New York: Farrar, Straus and Giroux, 2014), 185.

64 Assmann, Cultural Memory and Early Civilization: Writing, Remembrance, and Political Imagination, 111.

65 Kajian mendalam tentang jiwa dan identitas, dapat dibaca dalam Richard D. Ashmore dan Lee Jussim, Self and Identity: Fundamental Issues (Oxford: Oxford University Press, 1997).

66 Assmann, Cultural Memory and Early Civilization: Writing, Remembrance, and Political Imagination, 113.

67 Ibid.

68 Ibid.

69 Ibid.

70 Ibid.

71 Ibid., 114.

72 Ibid.

73 Ibid., 115.

74 Benedict Anderson, Language and Power: Exploring Political Cultures in Indonesia (Ithaca: Cornell University Press, 1990).

75 Denys Lombard, Nusa Jawa: Silang Budaya Kajian Sejarah Terpadu, trans. oleh Winarsih Partaningrat Arifin, Rahayu S. Hidayat, dan Nini Hidayati Yusuf, vol. III: Warisan Kerajaan-Kerajaan Konsentris, III vol. (Jakarta: Gramedia Pustaka Utama, 2008).

76 M. Rusli Karim, Negara dan Peminggiran Islam Politik: Suatu Kajian Mengenai Implikasi Kebijakan Pembangunan Bagi Keberadaan "Islam Politik" di Indonesia Era 1970-an dan 1980-an (Yogyakarta: Tiara Wacana `, 1999). Ismail, Ideologi Hegemoni Dan Otoritas Agama: Wacana Ketegangan Kreatif Islam Dan Pancasila. Oetojo Oesman dan Alfian, ed., Pancasila Sebagai Ideologi dalam Berbagai Bidang Kehidupan Bermasyarakat, Berbangsa dan Bernegara (Jakarta: BP-7 Pusat, 1992). 
77 Samuel, Genealogi Kekuasaan Ilmu Sosial Indonesia: Dari Kolonialisme Belanda Hingga Modernisme Amerika.

78 Benedict Anderson, Imagined Communities: Reflections on the Origin and Spread Nationalism (New York: Verso, 2006), 36.

79 Jocelyn Maclure dan Charles Taylor, Secularism and Freedom of Conscience, trans. oleh Jane Marie Todd (Cambridge: Harvard University Press, 2011), 22-23.

80 Karya paling komprehensif tentang sekular, baca Charles Taylor, A Secular Age (Cambridge: The Belknap Press of Harvard University Press, 2007). William H. Swatos Jr. dan Kevin J. Christiano, "Secularization Theory: The Course of a Concept," Sociology of Religion 60, no. 3 (1999): 209-28. Rick Phillips, "Can Rising Rates of Church Participation be a Consequence of Secularization?," Sociology of Religion 65, no. 2 (2004): 139-53. Loek Halman dan Veerle Draulans, "How secular is Europe?," The British Journal of Sociology 57, no. 2 (2006): 263-88.

81 Taylor, Dilemmas and Connections: Selected Essays, 304.

82 Swatos Jr. dan Christiano, "Secularization Theory: The Course of a Concept," 212.

83 Taylor, Dilemmas and Connections: Selected Essays, 304.

84 Anderson, Imagined Communities: Reflections on the Origin and Spread Nationalism, 46.

85 Timothy L. O’Brien dan Shiri Noy, "Traditional, Modern, and Post-Secular Perspectives on Science and Religion in the United States," American Sociological Review 80, no. 1 (2015): 92.

86 Justus M. Van Der Kroef, "Society and Culture in Indonesian Nationalism," The American Journal of Sociology 58, no. 1 (1952): 11-24.

87 Howard M. Federspiel, "Islam and Nationalism," Indonesia, no. 24 (1977): 39-85.

88 Howard M. Federspiel, Sultans, Shamans, and Saints: Islam and Muslims in Southeast Asia (Chiang Mai: Silkworm, 2007).

89 Laffan, Islamic Nationhood and Colonial Indonesia: The Umma Below the Winds.

90 Michael Franciss Laffan, The Making of Indonesian Islam (New Jersey: Princeton University Press, 2011).

91 Anderson, Imagined Communities: Reflections on the Origin and Spread Nationalism.

92 Benedict Anderson, Spectre of Comparisons: Nationalism, Southeast Asia, and the World (Manila: Ateneo de Manila University Press, 2004).

93 Charles E. Fahardian, Christianity, Islam, and nationalism in Indonesia (New York: Routledge, 2005).

94 Jennifer Lindsay dan Maya H.T. Liem, ed., Heirs to World Culture: Being Indonesian 1950-1965 (Leiden: KITLV Press, 2012).

95 Komaruddin Hidayat dan Ahmad Gaus A.F., ed., Menjadi Indonesia (Bandung: Mizan, 2006).

96 Alagappa, Nation Making in Asia: From Ethnic to Civic Nations?

97 Ibid., h, 6. 
98 Gungwu Wang, Nation-Building: five Southeast Asian Histories (Singapore: ISEAS, 2005).

99 Reid, Imperial Alchemy: Nationalism and Political Identity in Southeast Asia.

100 Mengenai studi etnisitas dan kebangsaan, baca Thomas Hylland Eriksen, Ethnicity and Nationalism (New York: Pluto Press, 1994).

101 Nicholas Tarling, Nationalism in Southeast Asia (New York: Routledge, 2004).

102 Joel S. Kahn, Other Malays: Nationalism and Cosmopolitanism in the Modern Malay World (Singapore: Singapore University Press, 2006).

103 Mengenai pendekatan yang dia gunakan lihat juga Joel S. Kahn, "Anthropology as Cosmopolitan Practice?,” Anthropological Theory 3, no. 2 (2003): h, 403 15.

104 Joel S. Kahn, Minangkabau Social Formations: Indonesian Peasants and the World Economy (Cambridge: Cambridge University Press, 1980).

105 Djoko Santoso, Menggagas Indonesia Masa Depan (Jakarta: Tebet Center 66 dan Komodo Books, 2014).

106 Ahmad Syafii Maarif, Islam dalam Bingkai Keindonesiaan dan Kemanusiaan: Sebuah Refleksi Sejarah (Bandung: Mizan, 2015).

107 Ali, Negara Pancasila: Jalan Kemaslahatan Berbangsa.

108 Yudi Latif, Negara Paripurna: Historisitas, Rasionalitas, dan Aktualitas Pancasila (Jakarta: Gramedia, 2011).

109 Ali Moertopo, Strategi Politik Nasional (Jakarta: CSIS, 1974).

110 Makmur Supriyatno, Tentang Ilmu Pertahanan (Jakarta: Yayasan Obor Indonesia, 2014).

111 Lawrence Freedman, Strategy: A History (New York: Oxford University Press, 2013).

\section{DAFTAR PUSTAKA}

Acemoglu, Daron, dan James A. Robinson, 2012. Why Nations Fail: The Origins of Power, Prosperity, and Poverty. London: Profile Books.

Alagappa, Muthiah, 2012. Nation Making in Asia: From Ethnic to Civic Nations? Kuala Lumpur: Institute of Strategic and International Studies (ISIS) Malaysia.

Al Gore, 2013. The Future. New York: WA Allen.

Ali, As'ad Said, 2010. Negara Pancasila: Jalan Kemaslahatan Berbangsa. Jakarta: LP3ES.

Anderson, Benedict, 2006. Imagined Communities: Reflections on the Origin and Spread Nationalism. New York: Verso.

— 1990. Language and Power: Exploring Political Cultures in Indonesia. Ithaca: Cornell University Press.

— 2004. Spectre of Comparisons: Nationalism, Southeast Asia, and the World. Manila: Ateneo de Manila University Press.

Ashmore, Richard D., dan Lee Jussim, 1997. Self and Identity: Fundamental Issues. Oxford: Oxford University Press.

Aspinnall, Edward, 2007. "From Islamism to Nationalism in Aceh, Indonesia." 
Nations and Nationalism 13, no. 2: 245-63.

, 2009. Islam and Nation: Separatist in Aceh, Indonesia. California: Stanford University Press.

—. "Sovereignty, the Successor State, Universal Human Rights: History and International Structuring of Acehnese Nationalism." Indonesia, no. 73 (2002): $1-24$.

Assmann, Jan, 2011. Cultural Memory and Early Civilization: Writing, Remembrance, and Political Imagination. New York: Cambridge University Press.

Azra, Azyumardi, 2003. Surau Pendidikan Islam Tradisional Dalam Transisi Dan Modernisasi. Jakarta: Logos.

Benda, Harry J. "Christian Snouck Hurgronje and the Foundations of Dutch Islamic Policy in Indonesia.” The Journal of Modern History 30, no. 4 (1958): 338-47.

Birch, Anthony H, 2001. The Concepts and Theories of Modern Democracy. New York: Routledge.

Bottignolo, Bruno, 1995. Celebrations with the Sun: An Overview of Religious Phenomena among the Badjaos. Manila: Ateneo de Manila University Press.

Bruinessen, Martin Van, 1999. "Kata Pengantar." In Geger Tengger: Perubahan Sosial dan Perkelahian Politik, oleh Robert W. Hefner, xxxi-xxxv. Yogyakarta: LKiS.

Bustamam-Ahmad, Kamaruzzaman, 2017. Kontribusi Charles Taylor, Syed Muhammad Naquib Al-Attas, and Henry Corbin dalam Studi Metafisika Eु Meta Teori terhadap Islam Nusantara di Indonesia. Banda Aceh: Bandar Publishing.

_. "Mempertimbangkan Kontribusi Charles Taylor terhadap Studi Agama di Indonesia." Episteme 11, no. 2 (2016): 225-59.

Bustamam-Ahmad, Kamaruzzaman, dan M. Hasbi Amiruddin, 2013. Ulama, Separatisme, dan Radikalisme di Aceh. Yogyakarta: Kaukaba and LSAMA.

Carter, April., 2001. The Political Theory of Global Citizenship. New York: Routledge.

Chua, Liana, 2012. The Christianity of Culture: Conversion, Ethnic Citizenship, and the Matter of Religion in Malaysian Borneo. New York: Palgrave.

Coomans, Mikhail, 1987. Manusia Daya: Dahulu, Sekarang, Masa Depan. Jakarta: Gramedia.

Cottam, Martha L., dan Richard W. Cottam, 2001. Nationalism EF Politics: The Political Behaviour of Nation States. Colorado: Lynne Rienner.

Covarrubias, Miguel, 1973. Island of Bali. Singapore: Periplus.

Cummings, William. "Islam, Empire, and Makasarese Historiography in the reign of Sultan Alauddin (1593-1639).” Journal of Southeast Asian Studies 38, no. 2 (2007): 197-214.

Darsa, Undang A., dan Edi S. Ekadjati, 2004. Gambaran Kosmologi Sunda. Bandung: Kiblat.

Day, Tony, dan Craig J. Reynolds. "Cosmologies, Truth Regimes, and the State in Southeast Asia." Modern Asian Studies 34, no. 1 (2000): 1-55.

Der Kroef, Justus M. Van. "Society and Culture in Indonesian Nationalism." The American Journal of Sociology 58, no. 1 (1952): 11-24. 
Dobbin, Christine, 2008. Gejola Ekonomi Kebangkitan Islam, dan Gerakan Padri: Minangkabau 1784-1847. Diterjemahkan oleh Tedjasudhana Lilian D. Depok: Komunitas Bambu.

Dorojatun, Kuntjoro-Jakti, 2012. Menerawang Indonesia Pada Dasawarsa Ketiga Abad Ke-21. Jakarta: Alvabet.

Eiseman, Fred B, 1990. Bali: Sekala and Niskala. Singapore: Periplus.

Eriksen, Thomas Hylland, 1994. Ethnicity and Nationalism. New York: Pluto Press.

European Internet Foundation, 2009. “The Digital World.” European Internet Foundation.

Fahardian, Charles E, 2005. Christianity, Islam, and nationalism in Indonesia. New York: Routledge.

Federspiel, Howard M, 1977. "Islam and Nationalism." Indonesia, no. 24 (): 39 85.

_ 2007. Sultans, Shamans, and Saints: Islam and Muslims in Southeast Asia. Chiang Mai: Silkworm.

Freedman, Lawrence, 2013. Strategy: A History. New York: Oxford University Press. Fukuyama, Francis, 2014. Political Order and Political Decay: From the Industrial Revolution to the Globalization of Democracy. New York: Farrar, Straus and Giroux. _ 2009. "Reconceptualizing Democracies and Empowering Them to Deliver." In Democracy in U.S. Security Strategy: From Promotion to Support, diedit oleh Alexander T.J. Lennon, 55-74. Washington DC.: Center for Strategic and International Studies.

- The Great Disruption: Human Nature and the Reconstruction of Social Order. New York: The Free Press, 1999.

- The Origins of Political Order: From Prehuman Times to French Revolution. New York: Farrar, Straus and Giroux, 2012.

Gard, Richard A. "Ideological Problems in Southeast Asia." Philosophy East and West 2, no. 4 (1953): 292-307.

Geertz, Clifford. "Form and Variation in Balinese Structure." American Ethnologist 61 (1959): 991-1012.

—. Local Knowledge: Further Essays in Interpretitve Anthropology. New York: Basic Books, 1983.

—. Negara:The Theatre State in Nineteenth-Century Bali. New Jersey: Princeton University Press, 1980.

- The Interpretation of Cultures: Selected Essays. New York: Basic Books, 1973.

- The Religion of Java. Chicago: The University of Chicago Press, 1960.

Halman, Loek, dan Veerle Draulans. "How secular is Europe?" The British Journal of Sociology 57, no. 2 (2006): 263-88.

Hamzah, Murizal. Hasan Tiro: Jalan Panjang Menuju Damai Aceh. Banda Aceh: Bandar Publishing, 2014.

Handler, Richard. "An Interview with Clifford Geertz." Current Anthropology 32, no. 5 (1991): 603-13.

Harun, Hairudin. Kosmologi Melayu dalam Era Teknologi Maklumat. Kuala Lumpur: Dewan Bahasa dan Pustaka, 2001. 
Hidayat, Komaruddin, dan Ahmad Gaus A.F., ed. Menjadi Indonesia. Bandung: Mizan, 2006.

Hikam, Muhammad AS. Menyongsong 2014-2019: Memperkuat Indonesia dalam Dunia yang Berubah. Jakarta: Badan Intelijen Negara (BIN) dan Rumah Buku, 2014.

Holbraad, Carsten. Internationalism and Nationalism in European Political Thought. New York: Palgrave Macmillan, 2003.

Inglis, Fred. Clifford Geertz: Culture, Customs and Ethics. Cambridge: Polity Press, 2000.

Institute for Security Studies. "Global Governance 2025: At a Critical Juncture." Paris: The European Union Institute for Security Studies, 2010.

Ismail, Faisal. Ideologi Hegemoni Dan Otoritas Agama: Wacana Ketegangan Kreatif Islam Dan Pancasila. Yogyakarta: Tiara Wacana ', 1999.

Jacobson, John A. An Introduction to Political Science. London: Wadsworth Publishing Company, 1998.

Kahn, Joel S. "Anthropology as Cosmopolitan Practice?" Anthropological Theory 3, no. 2 (2003): 403-15.

- Minangkabau Social Formations: Indonesian Peasants and the World Economy. Cambridge: Cambridge University Press, 1980.

—. Other Malays: Nationalism and Cosmopolitanism in the Modern Malay World. Singapore: Singapore University Press, 2006.

Kaku, Michio. Physics of the Future: How Science Will Shape Human Destiny and Our Daily Lives by the Year 2100. New York: Anchor Books, 2012.

Karim, M. Rusli. Negara dan Peminggiran Islam Politik: Suatu Kajian Mengenai Implikasi Kebijakan Pembangunan Bagi Keberadaan "Islam Politik" di Indonesia Era 1970-an dan 1980-an. Yogyakarta: Tiara Wacana `, 1999.

Kissinger, Henry. World Order. New York: Penguin Press, 2014.

Kuntowijoyo. Paradigma Islam: Interpretasi untuk Aksi. Bandung: Mizan, 2008.

__. "Radikalisasi Pancasila." Kompas. 212001.

Laffan, Michael Franciss. Islamic Nationhood and Colonial Indonesia: The Umma Below the Winds. New York: Routledge, 2003.

- The Making of Indonesian Islam. New Jersey: Princeton University Press, 2011.

Leahy, Loius. Kosmos, Manusia dan Allah. Yogyakarta: Kanisius, 1986.

Lindsay, Jennifer, dan Maya H.T. Liem, ed. Heirs to World Culture: Being Indonesian 1950-1965. Leiden: KITLV Press, 2012.

Lombard, Denys. Nusa Jawa: Silang Budaya Kajian Sejarah Terpadu. Diterjemahkan oleh Winarsih Partaningrat Arifin, Rahayu S. Hidayat, dan Nini Hidayati Yusuf. Vol. III: Warisan Kerajaan-Kerajaan Konsentris. III vol. Jakarta: Gramedia Pustaka Utama, 2008.

Maarif, Ahmad Syafii. Islam dalam Bingkai Keindonesiaan dan Kemanusiaan: Sebuah Refleksi Sejarah. Bandung: Mizan, 2015.

Maclure, Jocelyn, dan Charles Taylor. Secularism and Freedom of Conscience. Diterjemahkan oleh Jane Marie Todd. Cambridge: Harvard University Press, 2011. 
Magnis-Suseno, Franz. Etika Jawa: Sebuah Analisa Falsafi tentang Kebijaksaan Hidup Jawa. Jakarta: Gramedia, 2003.

M. Hasan, Husaini. Dari Rimba Aceh ke Stockholm. Jakarta: Batavia Publishing, 2015.

Maunati, Yekti. Identitas Dayak: Komodifikasi dan Politik Kebudayaan. Yogyakarta: LKiS, 2004.

Mee, Wendy. "A Traffic in Songket: Translocal Malay Identity in Sambas." Journal of Southeast Asian Studies 41, no. 2 (2010): 331-329.

Mickey, Sam. On The Verge of a Planetary Civilization: A Philosophy of Integral Ecology. London: Rowman \& Littlefield International, Ltd, 2014.

Moertopo, Ali. Strategi Politik Nasional. Jakarta: CSIS, 1974.

National Intelligence Council. "Global Trends 2015: A Dialoque About the Future With Nongovernement Experts.” National Intelligence Council, 2000.

_. "Global Trends 2025: A Transformed World." National Intelligence Council, 2008.

. "Global Trends 2030: Alternative Worlds." Director of National Inteligence, 2012.

. "Mapping the Global Future: Report of the National Intelligence Council's 2020 Project." National Intelligence Council, 2004.

Nimmo, H. Arlo. Magosaha: An Ethnography of the Tawi-Tawi Sama Dilaut. Manila: Ateneo de Manila University Press, 2001.

Oberman, Raoul, Richard Dobbs, Arief Budiman, Fraser Thompson, dan Morten Rosse. "The Archipelaco Economy: Unleashing Indonesia's Potential." McKinsey Global Institute, 2012.

O’Brien, Timothy L., dan Shiri Noy. "Traditional, Modern, and Post-Secular Perspectives on Science and Religion in the United States." American Sociological Review 80, no. 1 (2015): 92-115.

Oesman, Oetojo, dan Alfian, ed. Pancasila Sebagai Ideologi dalam Berbagai Bidang Kehidupan Bermasyarakat, Berbangsa dan Bernegara. Jakarta: BP-7 Pusat, 1992.

Otto Syamsuddin, Ishak. Aceh Pasca Konflik: Kontestasi 3 Varian Nasionalisme. Banda Aceh: Bandar Publishing, 2013.

Ozkirimli, Umut. Theories of Nationalism: A Critical Introduction. London: Palgrave Macmillan, 2010.

Pew Research Center. "A Portrait of Jewish Americans.” Washington, D.C.: Pew Research Center's Forum on Religion \& Public Life, 2013.

. "Faith on the Move: The Religious Affiliation of International Migrants." Washington, D.C.: Pew Research Center's Forum on Religion \& Public Life, 2012.

. "Global Christianity: A Report on the Size and Distribution of the World's Christian Population.” Washington, D.C.: Pew Research Center's Forum on Religion \& Public Life, 2011.

. "The Future of the Global Muslim Population: Projections for 2010-2030." Washington, D.C.: Pew Research Center's Forum on Religion \& Public Life, 2011 
—. "The Global Religious Landscape: A Report on the Size and Distribution of the World's Major Religious Groups as of 2010.” Washington, D.C.: Pew Research Center's Forum on Religion \& Public Life, 2012.

_ _. "U.S.Religious Landscape Survey Religious Beliefs and Practices: Diverse and Politically Relevant.” Washington, D.C.: Pew Research Center's Forum on Religion \& Public Life, 2008.

Phillips, Rick. "Can Rising Rates of Church Participation be a Consequence of Secularization?” Sociology of Religion 65, no. 2 (2004): 139-53.

Poespowardojo, T.M. Soerjanto, dan Alexander Seran. Filsafat Ilmu Pengetahuan: Hakikat Ilmu Pengetahuan Kritik terhadap Visi Positivisme Logis, serta Implikasinya. Jakarta: Kompas, 2015.

Puniatmaja, Oka. "Dharma, Pancasila dan Pembangunan Manusia Seutuhnya." In Agama dan Tantangan Zaman: Pilihan Artikel Prisma 1975-1984. Jakarta: LP3ES, 1985.

Raskin, Paul. "The Great Transition Today.” Boston: Tellus Institute, 2006.

Raskin, Paul, Al Hammond, Gilberto Gallopin, dan Rob Swart. "Branch Points: Global Scenarios and Human Choice." Sweden: Stockholm Environment Institute, 1997.

Raskin, Paul, Tariq Banuri, Gilberto Gallopin, Pablo Gutman, Al Hammond, Robert Kates, dan Rob Swart. "Great Transition: The Promise and Lure of the Times Ahead.” Boston: Tellus Institute, 2002.

Raskin, Paul, Gilberto Gallopin, Pablo Gutman, Al Hammond, dan Rob Swart. "Bending the Curve: Toward Global Sustainability." Sweden: Stockholm Environment Institute, 1998.

Raskin, Paul, Orion Kriegman, dan Josep Xercavins. "We the People of Earth: Toward Global Democracy.” Boston: Tellus Institute, 2010.

Reid, Anthony. An Indonesian Frontier: Acehnese $\mathcal{E}$ Other Histories of Sumatra. Singapore: Singapore University Press, 2005.

- Imperial Alchemy: Nationalism and Political Identity in Southeast Asia. Cambridge: Cambridge University Press, 2010.

Samuel, Hanneman. Genealogi Kekuasaan Ilmu Sosial Indonesia: Dari Kolonialisme Belanda Hingga Modernisme Amerika. Jakarta: Kepik Ungu, 2010.

Santoso, Djoko. Menggagas Indonesia Masa Depan. Jakarta: Tebet Center 66 dan Komodo Books, 2014.

Sastrapratedja, M. "Ideologi Pancasila Dalam Pembangunan Karakter Bangsa." In Budaya Bagi Bangsa, diedit oleh Toety Heraty Noerhadi, 142-60. Jakarta: AIPI, 2012.

Schmidt, Eric, dan Jared Cohen. The New Digital Age: Reshaping the Future of People, Nation and Business. London: John Murray, 2014.

Sibeon, Roger. Rethinking Social Theory. London: Sage Publications, 2004.

Simanjuntak, Bungaran Antonius, ed. Pemikiran tentang Batak Setelah 150 Tahun Agama Kristen di Sumatera Utara. Jakarta: Yayasan Obor Indonesia, 2011.

Supriyatno, Makmur. Tentang Ilmu Pertahanan. Jakarta: Yayasan Obor Indonesia, 2014. 
Swatos Jr., William H., dan Kevin J. Christiano. "Secularization Theory: The Course of a Concept.” Sociology of Religion 60, no. 3 (1999): 209-28.

Tarling, Nicholas. Nationalism in Southeast Asia. New York: Routledge, 2004.

Taylor, Charles. A Secular Age. Cambridge: The Belknap Press of Harvard University Press, 2007.

—. Dilemmas and Connections: Selected Essays. Cambridge: The Belknap Press of Harvard University Press, 2011.

—. Modern Social Imaginaries. London: Duke University Press, 2004.

. Sources of The Self: The Making of The Modern Identity. Cambridge: Harvard University Press, 1989.

Tiro, Hasan. "Konsep-Konsep Kunci Ideologi Acheh Merdeka." Suara Acheh Merdeka, no. VII (1996): 29-37.

Turner, Bryan S. Religion and the Modern Society: Citizenship, Secularization and the State. New York: Cambridge University Press, 2011.

Wahid, Abdurrahman. "Pancasila Sebagai Ideologi Dalam Kaitannya dengan Kehidupan Beragama dan Berkepercayaan Terhadap Tuhan Yang Maha Esa.” In Pancasila Sebagai Ideologi dalam Berbagai Bidang Kehidupan Bermasyarakat, Berbangsa, dan Bernegara, 163-68. Jakarta: BP-7 Pusat, 1992.

Wang, Gungwu. Nation-Building: five Southeast Asian Histories. Singapore: ISEAS, 2005.

Witkam, Jan Just. "Christiaan Snouck Hurgronje A Tour d'horizon of his Life and Work.” In Christiaan Snouck Hurgronje (1897-1936), 11-31. Leiden: Leiden University Library, 2007.

. "Introduction: Christiaan Snouck Hurgronje's Description of Mecca." In Mekka in the Latter Part of the 19th Century, oleh C. Snouck Hurgronje, xiiixxi. Leiden: Brill, 2007.

Yudi Latif. Negara Paripurna: Historisitas, Rasionalitas, dan Aktualitas Pancasila. Jakarta: Gramedia, 2011.

Zoetmulder, P.J. Manunggaling Kawula Gusti: Pantheisme dan Monisme dalam Sastra Suluk Jawa. Jakarta: Gramedia, 1995. 